University of Louisville

ThinkIR: The University of Louisville's Institutional Repository

Electronic Theses and Dissertations

1947

\title{
The first approximate conditions for the formation of mesomorphous coacervates.
}

Stanley H. Jury 1916-1983

University of Louisville

Follow this and additional works at: https://ir.library.louisville.edu/etd

Part of the Chemical Engineering Commons

\section{Recommended Citation}

Jury, Stanley H. 1916-1983, "The first approximate conditions for the formation of mesomorphous coacervates." (1947). Electronic Theses and Dissertations. Paper 1999.

https://doi.org/10.18297/etd/1999

This Master's Thesis is brought to you for free and open access by ThinkIR: The University of Louisville's Institutional Repository. It has been accepted for inclusion in Electronic Theses and Dissertations by an authorized administrator of ThinkIR: The University of Louisville's Institutional Repository. This title appears here courtesy of the author, who has retained all other copyrights. For more information, please contact thinkir@louisville.edu. 


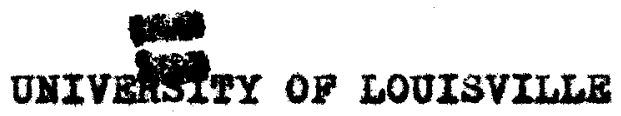

THE PIRST APPROXIUATH COKDITIONS

POR THE PORMATIOR OF

MESOLORPHOUS COACLRVATES

\author{
A Thesi: \\ Subaitted to the Paoulty \\ of the Cradunte School \\ of the University of Loulav1110 \\ In Partial Fulfilinont \\ of the Requirements \\ Ior the Degree of
}

MASTER OP CHEMTOAL ENOIHBRRIHO

Dopartmont of Chouteal Angineering

Stanleg H. Jury

September $\quad 1847$ 


\section{UNIVERSITY}

LIBRARIES

This PDF document is a scanned copy of a paper manuscript housed in the University of Louisville (UofL) Libraries. The quality of this reproduction is greatly dependent upon the condition of the original paper copy. Indistinct print and poor quality illustrations are a direct reflection of the quality of materials that are available for scanning. The UofL Libraries greatly appreciates any better copies that can be made available for replacement scans. 


\title{
THE PIRST APPROXIMATE CONDITIOUS \\ POR THE FORMATION OP \\ MEOMORPHOUS GOAOSRVATES
}

\author{
Stanley H. Jury
}

Approved by the Bramining Comenttees

Dirostor $\frac{\text { R. C. Ernst }}{\text { G. C. Williams }}$

Guy Stevenson 
CONMENTS

Page

List of Tables................................ in

List of Plgures............................. v

Aoknowledgement............................. v1

Abstrat.................................... v11

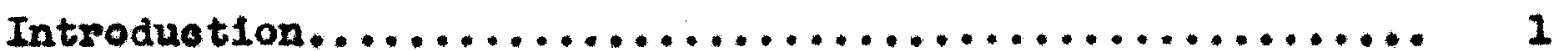

H1storisal ...................................

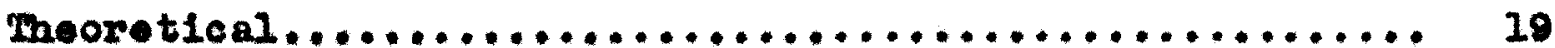

Brperimental................................. 26

Summary and Conolus1ons........................ 56

Iterature oited............................ 58

Appond1x................................. 63

List of symbola............................ 64

alossary............................... 66

Date on perimental solutions................. 68

Sample Calculations.......................... 74

Compounds Possessing Liquid Crystalline Phases in Solu-

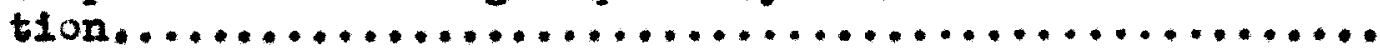

76

Coupounds Ilelding Sols Which Resemble Liquid Orys-

talilne Phoses..............................

80

B1bl1ography............................. 84

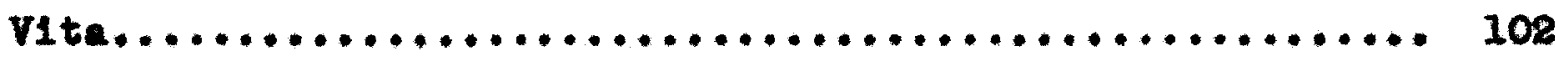


List of Tables

Táble No,

Page

I Wolght Concentration of Aqueous Sonp Solutions.... Heving two Phases in Equilibrium............... 10

II Molarity of Aqueous Soap Solutions Containing Two Phases in Equilibrium....................... 25

III Calculated Equilibrium Concentrations for Isoplestio Solutions............................ 47

IV Donsity of Aqueous Araranth Solutions at $20^{\circ} \mathrm{C} \ldots \ldots 66$

$v$ Donsity of Aqueous Hapthol Yellow S Solutions at

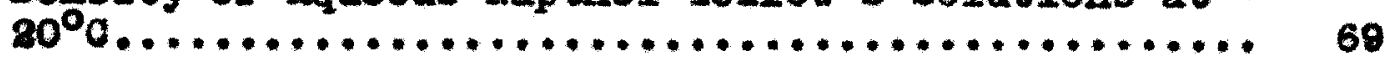

vI Starting and Bquilibrium Wolghts of Solutions..... 70

VII Thg Lowering of the Vapor Pressure of Water at.... $20^{\circ} \mathrm{C}$ Produced by Dissolved Potassium Chloride(49).

VIII Dengity of Aqueous Potassium Chloride Solutions at $20^{\circ} \mathrm{C}(48)$ 
List of Plgures

Pag• 18. 1. The Phase Dlagram of Dodoeyl Sulphonlo Aold and

F1g. 2. The Phase DLagram of Sodium Myristate and........

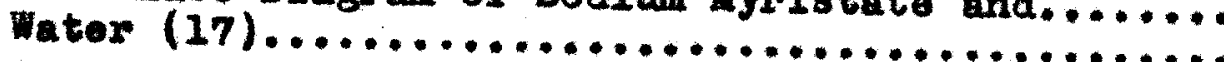

F1g. 3. Fleld Boundaries for Isotrop1c Aquoous Sonp Solutions (17)............................ 15

Fig. 4. Vaouum Deslecator, Framo and Auxi11ar10s........ 34

18. 5. Vacuum Deslcoator Partially Assembled Preparatory to Loading.............................. 34

P18. 6. Vacuum Dosiccator Loaded and Clamped in Framo.... 35

P1g. 7. Complete Deslecator and Frame Assembly Submerged
in Thermostat.....

F1g. 8. 4pparatus............................ 36

F1g. 9. Vapor Pressure Depression of Aquious Amaranth Solutions at $20^{\circ} 0 \ldots \ldots \ldots \ldots \ldots \ldots \ldots \ldots \ldots \ldots \ldots \ldots . \ldots 48$

PIg. 10 Vapor Prossure Depression of Aqueous Napthol..... Yellow S Solutions at $2000 \ldots \ldots \ldots \ldots \ldots \ldots \ldots \ldots \ldots, 48$

Fig. 11 Proposed Phase Diagram for the System Amaranth... and Weter.............................. 55

Fig. 12 Proposed Phase Dlegram for the System Naptho1.... Yellow $s$ and Water.......................... 
The auther w1 thes to acknowledge

the lind asstense and helpful guidanoe

of De. R. O. Inenat

wo directed this researoh 
Abstraot

An analgsis of the 11 terature hows the elose analogy betweon liquid erjstallino phases in solution (Mlulds separating from main portion of solution and having some of the directional propertios of oryutals) and unipolar coacorrates (solvated nicelles of $12 \mathrm{ke}$ ohargo soparating as a distinet oolloldal phose). A thoory is hore adranced that 11quid oryotalline phasos in solution are the direat result of a maximum in osmotie preauxe wioh is prodletable rrom the elrat approxtwate equation of the Dobje-Euckel thoory in the same manner as unipolar coacervates were prodieted by I. Langmuir. Application of the theory to aqueoua soaps, Investigated by Vold and assoalates, and to aquoous 10-brome or 10-ohlorophoanathrone6-aulphonle acld has shom remarleably good agroemont. As a furthos stop toward tosting the thoory a study has boon made of the osmotis beharior of aquoous Amaranth and Ilapthol Iollow s solutions at $20^{\circ}$, utilising the indireet wothod of enlevint1on based on monsuremont of the concentrations of 1soplestie solutions. The suppesition that these dres have 11quid eryotalline phases in aqueous solution has beon confirmed by plots of molar concentration vorsus oxmotle prossure which show discontinulties leonstant osmotie pressure over a range of concontration) indleating two Ilquid phases in equilibrive namely, the Ilquid orystaline phese and lsotroplo solution. In the 
case of Hapthol Yellow $S$ two discontinulties heve been doveloped below the normal limit of solublilty giten by Holmos whereas smaranth has only one. Thus a narrower coneentration range for the liquid orystalline phase is Indiested for the yellov. These facts have been interpreted utillzing proposed equilibrium diagrams. Application of the theory to the flrat (lowest concontration) discontinuity has shown good agreoment for Amaranth and less satisfactory agreomont for Napthol

Yollow S. In the latter case difforonoes botween fact and thoory have besn recoriolled based on differenses in moleoular structure. Predleting higher ordor transitiona is not oonsidered to be within the soope of the present theory besause fundemontelly the Debye-lickel first approximate equation is a dilute solution theory. Moreover, the equation would be expeoted to show agreemont only when the mass is 1sotropio regardless of conoentration: The faet that the equation takes no account of molecular constitution other than atate of oharge (Ionto valonoe) is amphasized. It has boen oonoluded that the presont thoory is highly satisfactory provided it is not applied Indisoriminately. 
IXTRODUCTIOI 
Industries interested in applying now materials to manufaeturing proeesses are oblefly concerned with predieting the physieal character of these materials. They are equally interested in completing thelr knowledge of the old materials If for no other reason than to establiah a basis for comparison. This is true of Industrie manufacturing dyes, pigments, wetting agents, paper, plasties, palnts, printing inks.

Naterials wiah doviate from the established laws of phyaleal chonlstry are partieularly troublesome. There are, for exumple, dyes and other compounds whloh dissolve in a solrent to produce apparently true solutions without any evidence of supersaturation. Yot these solutions possess some orystalline properties and for this reason have been assoolated with the names 11quid erystal, orystaline 11quid, mesophase, or anlsotropio Iluid. They also exhlbit anomalous viscosities and indistinot phase separation whioh are diffloult if not imposiblo to prodiet.

There are, on the other hand, certain oolloldal soIutions wose soparation into two 11quid phases (ooseorvation) can be predieted based on a lmomledge of oamotlo oharaoter. These eollolds possess mioelles of 11ke charge, consequently the separating phase has been named unipolar coacervate, whioh mFor moenings of specifie words see glosaary. 
- loselj resembles liquid orystals in solution. Consequently one might belleve that the aame baslo idea for prodieting unipolar coacervating conditions might also bo applied to liquid orjstals in solution.

It 1s, in fact, the purpose of this investigation to (a) examine the osmotle oharacter of two supposedly liquld crystaline solutions (aqueous Amaranth and Irepthol Yellow 3 dye solutions) and (b) show that the conditions under which 11quid orystallinity in solution will oocur are Identioal with those for unipolar concervates. 
HISTORIOAT, 
Hitherte the distinstion botween liquid orystalisnIty and coacervation has been one of prinelple rather than degreef consequently the study of each has been quite independent of the other. These studies hare been grouped as followst (a) 11quid orjstalline melts, (b) coeeervation of o01101ds, and (e) 11quid orystalline solutions. 0. Lehman (1) In 1888 was perhaps the first to observe that certain orjstals melted to give an opaque rluid wich we anisotroplo and whioh at some highor temperature eleared to give the normal isotrople molt. Subsequent investigations revealed that there were different types of antsotrop1e nelts. C. Priedel (2) has assigned the name Homatio mesophase to those exhib1ting thread 11ke strueture, and smect1e to those having soap 11 ke atruoture and oxhlbiting GrandJean terraces (an optieal figure), foeal conies (an optloal (1gure), and the 11ke. Oholeateryl was name givon to a third olass which he later onnidered to be Hematic.

Many have examined the onuses for the existenee or antsotropis molts; and al though there is atill considerable disagrement, it is generaliy acoepted that fundumentaliy they are due to partienlar eleotrieal forees poeuliar to the moleoules involved. In the ease of Homatie type molts the Swarm theory (3) of Bose is favored. The term "Swarm" is applied 
because It is hypothesised that the optical peouliarities are due to aggregates of oxiented molooules. It Is interesting to note that the liemat1e phase will orlent on a brushed surface, and as Lamrenes (4) points out, the elootrie momont of a Swarm is $10^{5}$ that for single moleoules and thus a high degree of association mat be expectod.

Vorlander (5) examined liquid orystalline molts in relation to thelf moleoular atruature. Ho discovered that Iinear type molecules farored liquid orystallinity and that mbstituent groups and thalr position detormined the degree and type of liquld erystal formed. P-axoxyanisole is charaetoristio of the Iomatio type while p-axoxy bonzolo di-othyl ester 1s typleal of the smectlo form. Many hundreds of 1lquid cryatalline compounds were snthoulzed varying in molecular welghts and ranging as high as 1000. Vorlander also domonstrated that certaln binary mixtures of 1sotroplo molts gave anisotropio molts. Ho also prepared compounds whloh had as hlgh as five elearing points, there being an anisotrople fluld between each suecessive palr of oloaring points as woll as botwoen the melting point and the elrst (lowest temperature) clearing point.

Betroon the tiwe of Vorlandor's sumery in 2825 and the Faraday Socioty Symosium (6) In 1933 the subjoet or Coacervation appears in tho 11terature. Bungenberg do Jong and knujt (7) disoovered a sort or "umixing" in oertain solutions 
or oollo1ds and leter in supersaturated solutions or Inorganie selts. In 1930 they proposed the name Ooacerration for the proeses of separation and Coscervate for the denser solution. whleh separated from the orlginal. Two types of concervates were reoognlzed. The simple coveervate, which oane from $001-$ loldal partiolos of like charge, was distinguishod from the complex coacervate arielng from blpolar lyophill oolloldel soIution. A hydration theory was proposed to explain oomplex coacervation phonomona.

Dobry (8) domoratrated that collulose acetate and ohloroform oan form a concorvated syotem, the stabllity belng due to the noarly Identioal donsities of coabervated and $11 \mathrm{q}-$ uid phase. With oellulose acetate, othyl aloohol and ohloroform the compounds of high molecular wolght are in the coseervated phase and the compounde or low moleeular weight in the 1iquid phase. The osmotic pressure of tho conoorvate phase, found by plotting apoed. of elltration through donitrated oollodion and oxtrapolating to sero speed, was found experimentally to be equal to the osmotio pressure of the solutions in equiIlbrium with 1t. The region of coacorvation lies in the region of lower osmotic prossures in this region the osmotic pressure of the Ilquid in equilibriun with the oovervated phase is small but 1s proportional to the coneontration. The analogy between a coacervate systom and liquid rapor system is lintted because small pressure applied to a cocervate phase 
oan cause tromendous doorease in volume of that phave: this, whe points out, is contrary to the bohevior of 11quida. Who Ilquid loat by the coaeervate phase 1s not appreciably reabsorbed. Van der Waala equation is not oonsidered applioable to oencervation.

Langmair (9) consider complex coscervates as contalning positive as well as negative mieelles and therefore prefore the name bipolar coscervates. Whe hjdration theory of Bungenberg de Jong $1 \mathrm{~s}$ accopted as applisable to this typo coneervate. Unipolar conservates are those from colloids harling charged partiolos wioh are coacerrated by the add1tion of a alt containing polgralent lons of opposite sign. The formation of taetolds from thlrotrop 10 sols, of ach1ller lajers from iron oxide sols, the separation of tobacco virus solutions and bentonite sols into two 11quid layers and the orystallization of protelns are regarded by Langmulr as examples of unipolar coacervation (micelles having like charges) which may involve attraetive forees.

Languris has shom that the Coulomb attraction betweon the mleelles and the oppositely charged lons in the soIution gives an excess of attractive foree which must be balanced by the dispersive aetion of thermal agitation (as a flest approxlmation) and another repulaive foroe(which, although operative, is not apeolfleally troated in the theory). Thus he contends that there is no need to assume long range van der Waals forees. He has orttolzed the past uge of energy dia- 
gram beanuse it has 1 gmored tho effect of the thermal agltation and the attraction of the "gegenions" (oounter lons) in solution. Instead of potential energJ he proposed thet osmot10 presmure, P, be used which includes these previously neglooted factors. A maximum in $P$ as the collold concentration increases is the condition for the separation into two phases (ooacervation).

Acoording to Langmuir the Debye-Huokel (10) thoory (first approximate equation) for the osmotic pressure of electrolytes takes into aooount both these factors and permits a rough caleulation of the conditions under whloh coacerration ocours. The sooond approximate equation, whloh cons1ders part10le al o does not agree so well with experimont as the first approximation. The reasons for this laok of agreamont are disoussed.

Onfortunately the work of Langmulr was not concerned with the physleal determinationa of osmotio pressure sach. The mathomatioal theory was based almost ontirely on optloal observation. H1s remalns a theory whlah st1ll requires oxperimontal proof. Speciking of doveloping a quantitatire theory by substitution of a new radius for the Debye-Huekel radius peramotor Langmulr conoludess

It hardly sooms worth while to develope a theory along suoh lines unt1l we have far bettor quantitutivo oxporimental date on unipolar concorvation w1th $001-$ lolds having partioles of ynown oharecter. 
Although the earlier investigations of Ilquid orystalline solutions wore carried on coneurrently with those of liquid orystalline melts, the former have been the less extenalve of the two. The vlews wore quite difforent from those for molts and in certain respeots became much more complex. In general there appeared to be two olesses of liquid erystals in solution; (a) those bolng or rosembling cortain fatty acld salts and (b) those forming in what are nomally considered to be true solutions. Zochor ot al (1I) Investigated the f1rst olass and roported that potassium and sodium oleate, ootyl xanthate, commerelal 10o1thin, and sodium napthenate gave Smoat10 11quid oxystaline solutions.

Table I. Wolght Conoentration of Aqueous Soap Solutions Having Two Phases in Iquilibrium Sodium Iaurate

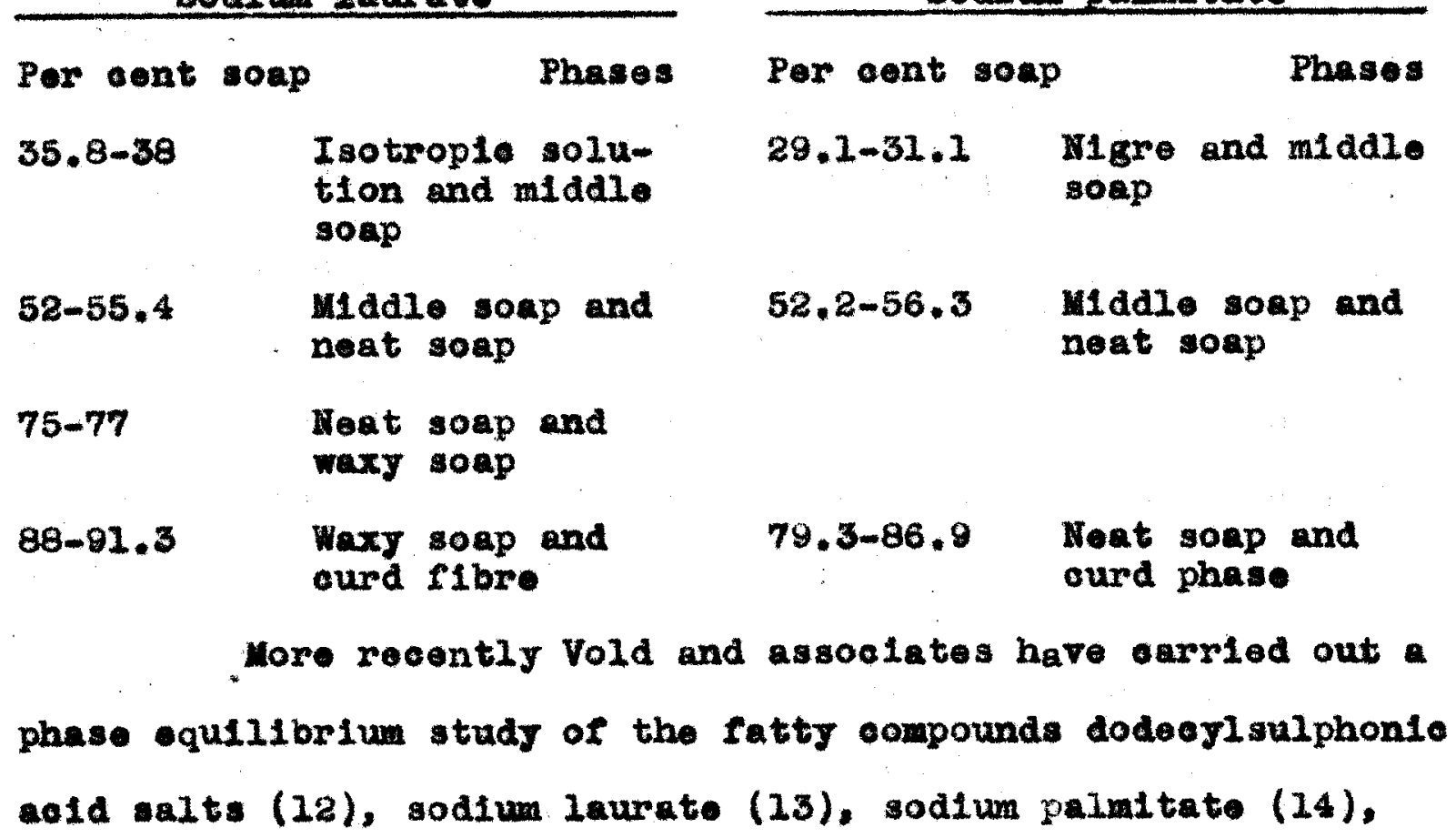


sodium stearate (15), sodium oleate (16), sodium mgristate (17), hexanolanine oleate (18), and others, It has been ahow, for example, that the vapor pressure concentration ourves for aqueous sodium laurate and sodium palmitate at $90^{\circ} \mathrm{C}$ oxhiblt rlata as shom in Table 1. The rlats have boen interproted as Indication of the coexistenoe of two phares in equilibrium also shown in Table 1 .

The phase equilibria atudy also inoluded solublilty determinations and dilatometric measurements on the aqueous soap solutions. In the aase of sodium myristato and dodeogloulphonte aold the data have been presented in the form of equilibrium diagrame reproduced in Figures 1 and 3 , Flgure 3 Is a sumenary of Volds work. It an be seen that rlats in the vapor pressure curve represent the intervals of conoentration on the equilibrium diagram corresponding to the section of shaded areas whioh are out by the $90^{\circ} \mathrm{O}$ ordinate. It w11 also bo shown later that one of these intervals (probably that ocourring at lowest conoentration)is as would bo expeoted from the Debye-Huakel theory.

The second olass of liquid orystals in solution rocelved the ettention of some of the carlier Investigators, The problew of accounting for the existonce of thls olasa was attaoked by Zooher (19) from the standpoint of ohomloal conIt1tution muoh the same as Vorlander did with molts. The toahnique was different in that Zoohor dissolved avallable compounds In aloohol and applled them to rubbed surfaces to 
deteot the presenoe of I1quid orystals. Sinoe Methylone Blue gave positive results he tested manj hundreds of other dyes and found that Neutrel Red and very fow others gave a more or less feeble test. Whe results foreed the conelusion that the property was largely confined to dyos of the azine, oxazino and thiazine classes.

Gaubert retested Hethylene Blue (20) and Neutral Red in aqueous solution in addition to many othex dyea ospeoially those with para substituents and added to the I1st the dyes Bxilliant Orocein (21) and Tartrazine (22) and also p-anlnoazotoluone (23) whioh gave 11quid orystals in a variety of organio solvents. The disturbing frotor was that molooular symetry, molooular IInearity and para substituents no longer determined 11quid orystallinity as was the oase for the melts prepared by Vorlander.

The recent woxk of Branner (24) with aqueous Potasslum Methyl Orange shows that this compound also produses 11quid orystalline solutions. The equilibrium diagram for the aqueous agstem is not unlike those for soaps which have been Investigated by Vold. Iiquid orystals soparate rrom lsotrople aolution along the boundary 0.5 molar $-80^{\circ} \mathrm{c} .1$ molar $-55^{\circ} \mathrm{O}$ and 0.02 molar- below room tomporature.

About 1915 Sandqrist propared a series of phenanthrene oompounds and found that the 10-bromo- and 10-ahlorophenanthrene-6-sulphonio ae1d (25) (26) (27) ras 11quid 


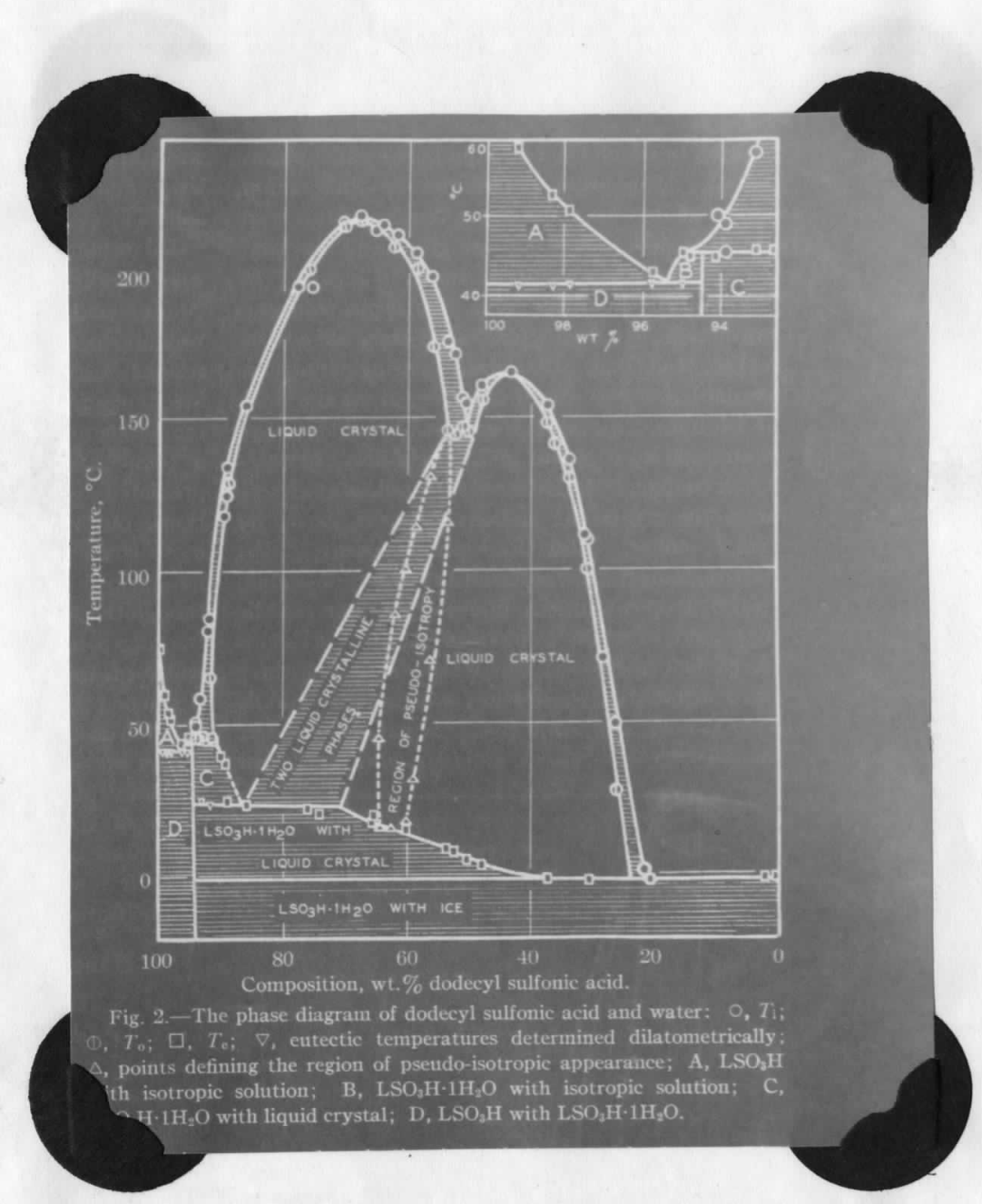

Fig. 1. The Phase Diagram of Dodecyl Sulphonic Acid and Water (12) 


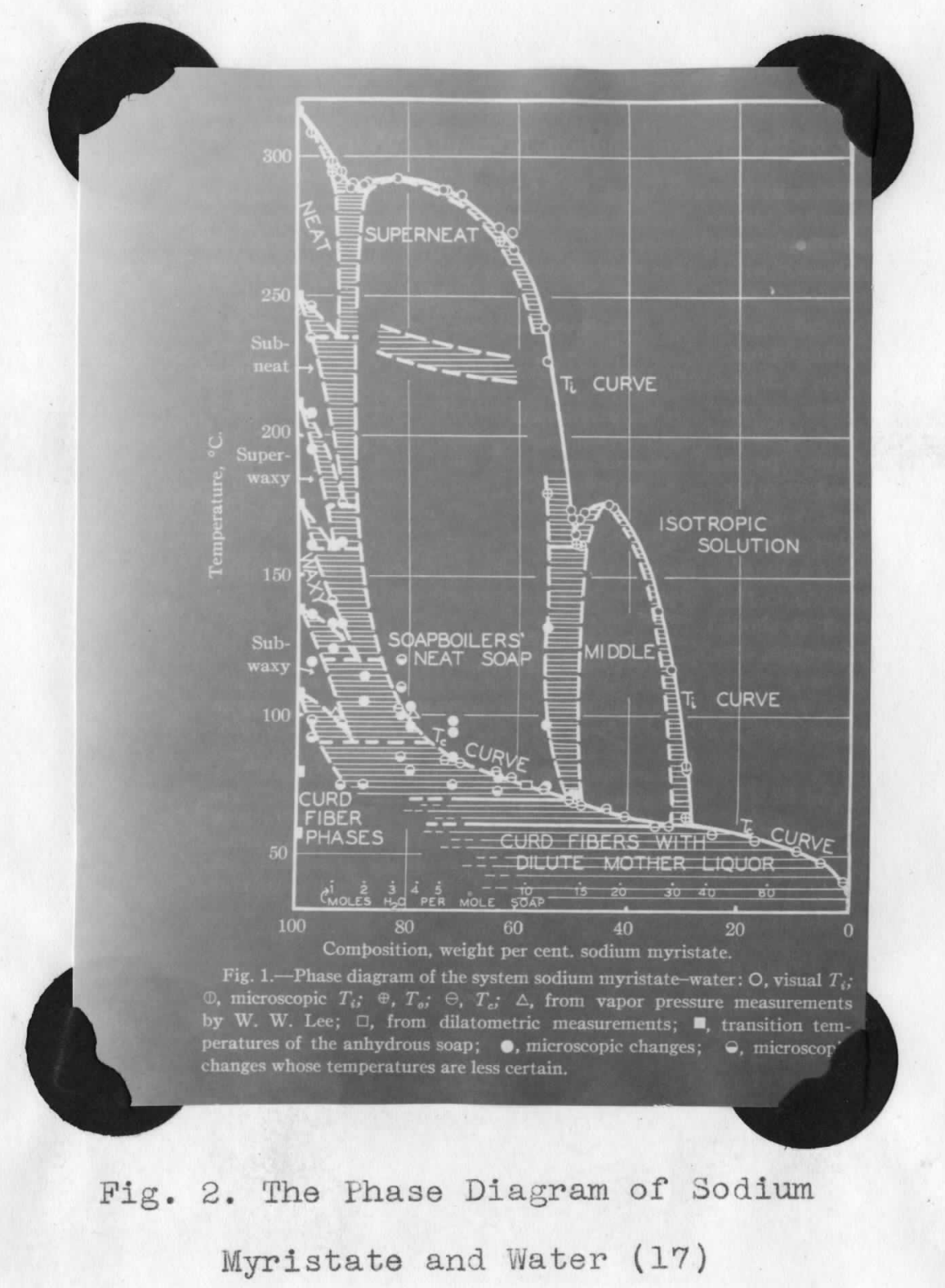




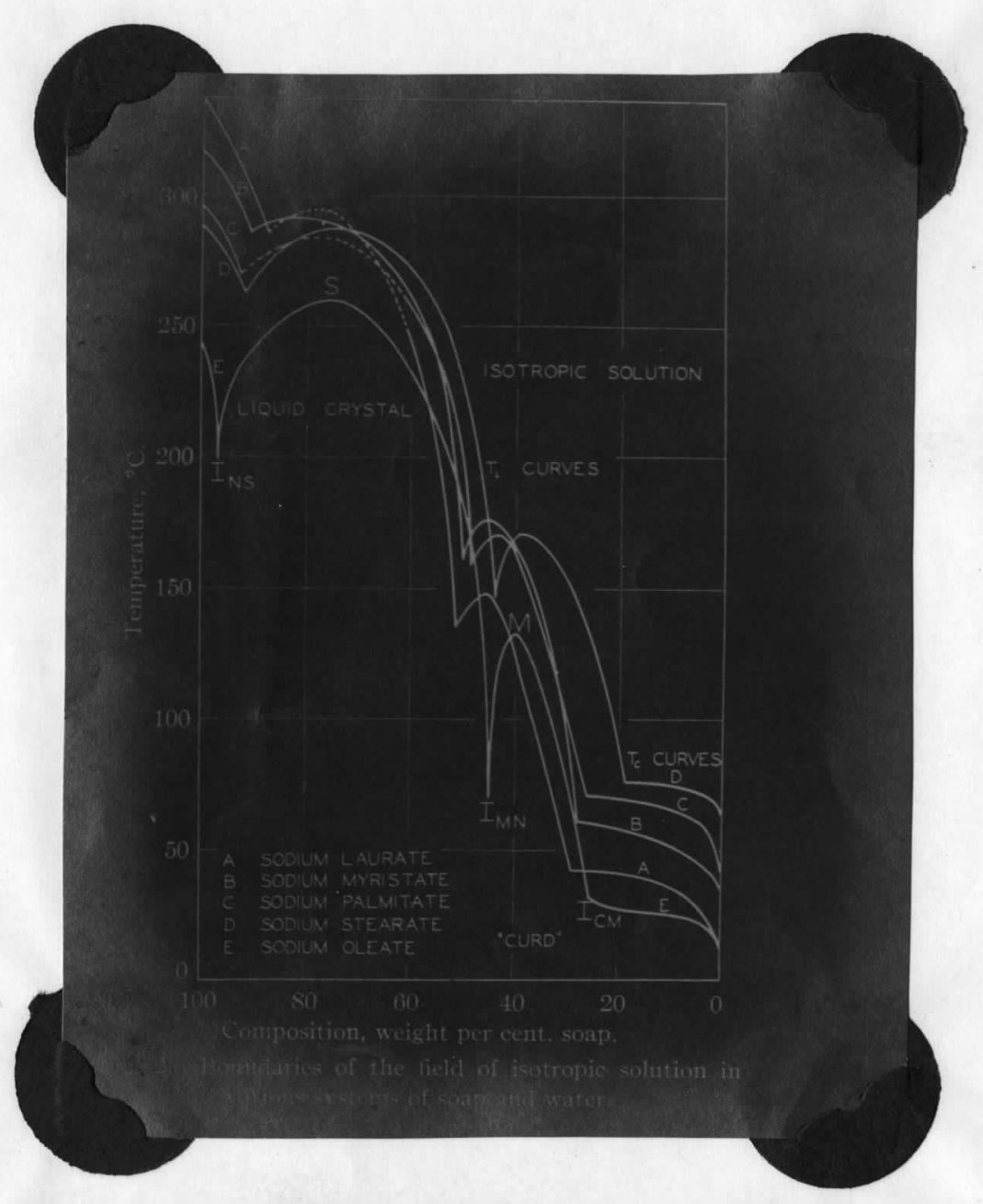

Fig. 3. Field Boundaries for Isotropic Aqueous Soap Solutions (17) 
orystalline in water: whereas the $10-3-(28)$ varieties as noll

as the disulpho-eompounds (29) were not. For a detalled des-

oription of his findings one maj quote from the abstraets (30)

$(31)(32) t$

Solutions of 10-bromophenanthrene-6-sulphonie aold in water show olouding at a tomperature which 1s definite for any alnglo conoentration and is the sem whethor moasured with rislng or fall1ng touperature. The molecular welght determined from freozIng point is about 1300. To euperaaturation is oonneeted with the clouding of the solution; and no marked offect acsompanies the separation of the phases. It was hown in the ultranloroscope that the solution was anisotropie. At a magnifetion of 300 the Ilquid showed the rounded drops and strueture of an anisotrople 11quid, and there was a coles play when the analyser was roteted. Tho optieal properties and the existenes of a eritieal polnt ostablithes the presenes of 11quid erystals in the soIution. Masuroment of the electrical conduetivity and $\mathbf{i s c o s i t y}$ are in progreas.

Investigation of the riseosity and optieal properties of equeous solutions of 10-bromophenanthrene6-alphonie aold has ahom that the colloldal obomienl nature of the solutions varies in a very extxisordinary way with the oonsentration. In dilute soIution the seld behares like an oxdinary eleotro1yte, bat as the concentration inereases the solution becomes more and more colloldal in character and ultimately a third stage is reached when the isotroplo solution comes to resemble very olosely a orystaline Ilquid. Fall of temperature has the same effect ar Inorease of coneontration and alvilar changes are brought about by the addition of certain forelon subatanees. The riseosity of the laotrople colloldal colution Inoreases rery repldiy with the conoentration of tho acld and tho tomperature soerfielent of the viveosity is much greater than that of volutions of oxystallolds, but the eleotrienl oonduetivity remalns approxlmately nowmal even when the V1seosity has beoome rery large; Oryoreople meesuremonts indleate that the molecular weight of the aeid is mak greater in soncentreted than in 11ute solutions. Eydroghlorio ne1d, nitrie no1d, and oulphurie ec1d produse muoh the wame effeot as 
Inorease In conoentration; weaker aolds, as acotic and ohloracetie have no approoleble infiuenoe, and suorose is muah less eotive than the mineral aolds. These ehanges neen to be completely determined by the oonoentration, tempereture and forelgn substances in the solution and Independent of the previous histort of the solution. There 1s no chango in visoosity marking the change from 1sotrop10 to anisotroplo condition. The temperature at whioh the 1sotrop10 collo1del solutions are tranaformed into oryotalino Ilquids axe murply dofinod and depend onif on the coneentration of the sulphonle acld and on the nature and quantity of the forelga substances present.

The 10-ohloro and 10-bromophenthrene 6-sulphon10 aelds give anisotropie visoous 11quids. Both the ohloro and bromo compounds show at $18^{\circ}$ and $.04 \mathrm{II}$ solution viseosity of $1.03\left(\mathrm{H}_{\mathrm{O}} \mathrm{O}=1\right)$. To 600 of suoh a solution was added loe 3 hjorochloric aeld with reculting visoosity for the bromo derivative of 6.1 wh1lo the chloro dorlvative showe 140. DIlute alkall solution also producesin the ohloro oompound a srupy consisteney but does not affoot the bromo compound.

The formulae (33) for Sandquist aclds are
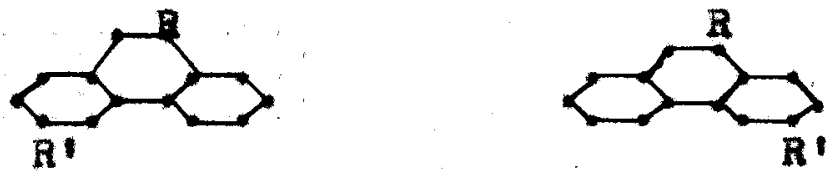

Where $R$ and $R$ are substituent radieal: (for example $R=01$ and $\left.\mathrm{R}^{\prime}=\mathrm{SO}_{3} \mathrm{IR}\right)$.

The exact senifleance of Sandquist indinge are far reaching. However, for the present work, the most igenifIcant point of all is that for those compounds giving liquid orystal in solution the dotermining oonditions wore (a) solute coneentration, (b) temperature, and (c) rorelgn elootrolyto coneentration. Had Sandquist used different solvents ho un- 
doubtedly would have added to these factors a fourth, (d) alelootric constant. Had he Ilved to witness publiention of the Bebje-fluckel rirat approximate oquation for prodioting ommotio pressure he would undoubtedly hare shom its applisab111ty here. 
THBORETTOAT. 
0lansias socording to choah (34) has derlsed an equet10n of state for the ommotio work which is freo from any arbltrary asauption. The equation as modified by the work of Chooh and Lowls and Randall (35) is

$$
P=\frac{n \operatorname{RT}}{\mathrm{V}}-\frac{m \mathrm{RTS}(1-9)}{\mathrm{s}}
$$

where

$$
\begin{aligned}
& P \text { - osmotic pressure (units oonsistent with R) } \\
& V=\text { rolum of solution (ee) } \\
& n=\text { number of noles of solute } \\
& T=\text { absolute temperature }\left({ }^{\circ} \mathrm{x}\right) \\
& g \text { osmotie cooffletent (almonsionless) } \\
& \text { A Egs constant (uamally ce. atmos./mole }{ }^{\circ} \mathrm{O} \text { ) }
\end{aligned}
$$

Rowriting equation 1, converting moles/oe. to iond 00. For the 1onle speeles $n_{1}, n_{2},-\ldots n_{1}$, with valenees $z_{1}$, $z_{2}$ - - - $z_{1}$ respectively, and subatituting the Lewle-Randall 1onic strength (36) for the lonie conoentration Insorar as it involres the osmotio ooffielent

$$
P=\operatorname{kr} \Sigma n_{1}-\frac{\operatorname{kr} 3(2-9) \Sigma\left(n_{1} z_{1}{ }^{2}\right)}{34}
$$

where $x$ is the Boltuman convtant.

Dobje and Euckel (10) have derived the expreaston

$$
(1-g)=\frac{e^{2}}{3 D x T}
$$

nex 
$\lambda=$ the Dabje distence $=\frac{\operatorname{Dkr} \sum\left(n_{1} z_{1}^{2}\right)}{\pi \theta^{2}}$

- unit of eleotrostatie oharge (esu)

$D=$ dieleotrie constant of solvent

Substitution of equation 3 in equation 2 produces the first approximate equation:

$P=k N \sum n_{1}-\frac{1}{3}\left[\frac{\pi e^{6}}{D^{3} k T}\right]^{\frac{2}{3}}\left[\Sigma\left(n_{1} z_{1}^{2}\right)\right] 3 / 2$

Equation san be reduced to more useful forms if attention 1s confined to two moleoular speoles. The one is a color moleoule with the color anion of concentration $n_{1}$ and valence $z_{1}$ and cation of concentration $z_{2}$ and valenoe $z_{2}$. The other 1s a forelgn elestrolyte of anion concentration $n_{3}$ and valence $z_{3}$ and oation conoentration $n_{4}$ and valence $z_{4}$. The oonditions for solution electrieal noutrality are then fulrilled if

$$
n_{2}=\frac{n_{1}{ }_{1}}{z_{2}}
$$

and

$$
n_{4}=\frac{n_{3} z_{3}}{z_{4}}
$$

Bxpanding equation and subatituting the equira-

lents for $n_{2}$ and $n_{4}$ from equations 5 and 6 respectively $P=\left[n_{1}+\frac{n_{1} z_{2}}{z_{2}}+n_{3}+\frac{n_{3} z_{3}^{4}}{z_{4}}\right] \times 1-\frac{1}{3}\left[\frac{\pi e^{6}}{D^{3}-T}\right]^{\frac{1}{2}}\left[n_{1} z_{1}^{2}+n_{1} z_{1} z_{2}+n_{3} z_{3}^{2}+n_{3} z_{3} z_{4}\right]^{3 / 2}$

or

$$
P=\left[n_{1} \frac{z_{1} z_{2}}{z_{2}}+n_{3} \frac{z_{34} z_{4}}{z_{4}}\right] k T-\frac{1}{3}\left[\frac{\pi e^{6}}{D^{3}{ }_{k T}}\right]^{3}\left[n_{1} z_{1}\left(z_{1}+z_{2}\right)+n_{3} z_{3}\left(z_{3}+z_{4}\right)\right]^{3 / 2}
$$

Determination of the maximum osmot10 pressure requires that $\frac{\partial P}{\partial n_{1}}=0$ for any solution w1th a fixed ooncentration of 
forelen electrolyte. Bquation 7 beoomes

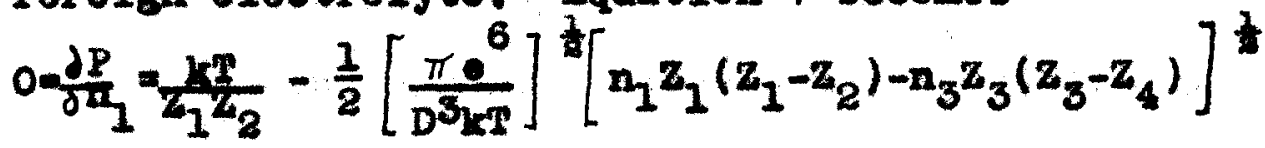

(1)

$$
n_{1}=\frac{\frac{4}{\pi}\left[\frac{D k t}{n^{2}}\right]^{3}}{z_{1}^{3} z_{2}^{2}\left(z_{2}+z_{2}\right)}-\frac{n_{3} z_{3}}{z_{1}}\left[\frac{z_{34} z_{1}}{z_{1}+z_{2}}\right]
$$

Substitution of this value for $n_{1}$ in oquation 7 and rearranglng

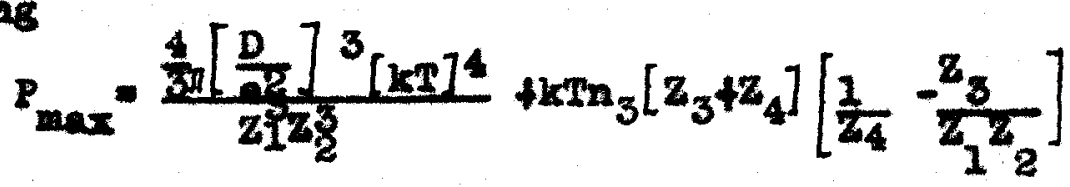

Substituting in equations 7,8 and 9 the recont ran Ajsselberghe constants (37)

$$
\begin{aligned}
& =4.8025 \cdot 10^{-10} \cdot 4 \mathrm{u} \\
& k=1.38047^{*} 10^{-16} \text { orgs } / 0 \\
& n_{1}=1 \text { ond / e }=6.0228 * 10^{20} a_{1} \text {, where } o_{1}=\text { molarity } \\
& n_{3}=n=n \text { " } \\
& \left(x=6.0288 \cdot 10^{83}\right) \\
& T=293.16^{\circ} \mathrm{K} \\
& \left(T_{0}=273.16^{\circ} \mathrm{K}\right)
\end{aligned}
$$

and ( 88$)$

$$
\begin{aligned}
D & =80-.4(t-20) \text { for water at } 0 \leq t \leq 100^{\circ} \mathrm{C} \\
& =80 \text { at } 20^{\circ} 0 \\
\pi & =3.14150
\end{aligned}
$$$$
\text { atmospheres }=9.8692 \times 10^{-7} \times(\text { erge/on.) }
$$$$
\text { ergo/co. - dymes/aq. am. }
$$

\section{gives the final results:}

$P=24.054\left[0_{1} \frac{z_{1} z^{2} z_{40}}{2} \frac{z_{3} z_{4}}{z_{4}}\right]-6.6313\left[c_{1} z_{1}\left(z_{2}+z_{8}\right)+0_{3} z_{3}\left(z_{3}+z_{4}\right)\right]^{3 / 2}(10)$ 
and at $P_{\text {mix }}$

$$
\begin{aligned}
& c_{1}=\frac{5.848}{z_{1}^{3} z_{8}^{2}\left(z_{1}+z_{2}\right)}-\frac{c_{8} z_{3}\left(z_{3}+z_{4}\right)}{z_{1}\left(z_{1}+z_{2}\right)} \\
& p_{\max }=\frac{46.896}{z_{1}^{3} z_{8}^{5}}+24.054 c_{3}\left(z_{3}+z_{4}\right)\left[\frac{1}{z_{4}}-\frac{z_{3}}{z_{1} z_{8}}\right]
\end{aligned}
$$

The thoory ing be applied to the fladings of Sandquist and Vold et al. Consider IIrat the Inorease in viscosity found by Sandgrist when 1 os of 3 nolew hydrochlorlo was added to 6 oc of .04 II (alse.04 molar for peasons to be diseunsed) sanderist aeld. Before the ecid wa addod, the approximnte ooneentration for Ilquid oryotelilnity is

$$
0_{1}-0.243 \text { molar (apparent) }
$$

and thus .04 normal solutions being sonsiderably below this linit would show low risoosity and no Ilquid eryatals. After the ecid wa added, the contrary is true for the chloro compound as indioated by equation 11 whioh beoomes

$$
c_{1}=0.243-0.143=0.10 \text { molar (appexent) }
$$

This is ressonablJ within the range of .04 1 oonsidering that the constant in equation 21 we eraluated at $20^{\circ} \mathrm{O}$; woreas the Sandqriet experiments were oaried out at $10^{\circ} \mathrm{O}$.

It $\mathbf{1 1 1}$ be noted in the computation of $o_{2}$ that the Sandqvint acid anion was considered 0.04 molar. JustificatIon 1 based on the assumption that the bond between onlexino and phonanthrone is auflelentiy polar to contribute to valenoe conelderations but 18 at the same time suffielently covelent 
to rosist titration (or ronets with dilute oustio so slowly as to escape attention). That the halogon bond is of quest1onable neture 1s shown by Sandqvist's report (39) that the ohloro compound gives up hydroohlorio aold as it molts. SimlIarly, 0. Lehman's work (40) with the bromo wold has shom that it is oasily soluble in aloohol but with subsequont decomposition and procipltation. It appoars that the bromo compound is an exception to the assumption in that it is probably .02 molar, and the bromine bond is more polar than thet for chlorine.

Treatment of the work of Vold ot al requires that equation 12 be corrected for $T-363.16$. The now constant is 3.053 and equation 11 beoomes

$$
c_{1}=\frac{3.053}{z_{1}{ }^{3} z_{2}{ }^{2}\left(z_{1}+z_{2}\right)}-\frac{a_{3} z_{3}\left(z_{3} z_{4}\right)}{z_{1}\left(z_{1}+z_{2}\right)}
$$

In this oase of pure solutions of uni-undralent soaps $c_{1}=$ 1.527 mold $/ 1$. (apparent). The approximate limits for the 1sotropie-middle soap equilibrium are linted in Table 2. The thoory agrees reasonably well in the case of sodium palmitate and excellently in the case of sodium laurate. Thus, the theory appears to be acoeptablo.

The question of predieting the higher order tranaltlons whioh dereloped from the work of Vold is not considered to be within the scope of the present thoory alnoe the first approximato equation is fundamentally a dilute solution thoory. 
Moreover the theory would be expected to show antlafactory agreement only when one of the equilibrium phases 1s 1sotrop1e regardless of oonoontration. Any attompt to acoount for the h1gher order transitions mast take Into consideration the additional forees or the now arrangement of forees oharactorising anlsotrop1o phasos (atruotures in solution).

Table II Wolarity of Aqueous Soap Solutiona Containing Tro Phases in Bquilibrium

Sodium laurato

$$
\text { 1. 56-1.67 }
$$

Sodium palmitate

$$
0.987-1.055
$$

Pinding in the ifterature numerous oxamples with whioh to tost the present theory is surprisingly diffloult. sotually those olted above are the result of a several months search. Oonsequently additional researah, partloularly on the osmotis character of certain of the acid wool dyes, is considered useful. These dyes have become the subject of Investigation based on experience which has shown that they exhiblt anomalles in solution paralleling those for other materials desoribed in the ilterature and moeting the exact deseription of liquid orystaliline solutions. 
EXPRRTMETTA

A. PURIPIOATIOA OF DYRS AID POTASSIUM GHLORIDE 
The commerolal dyes, Amaranth (0.185 Co.) and Iepthol Yellow s (Hational iniline Co.), were seloeted as the wubjeats of investigation. At first the method of Heale (4I) utilining sodiun cetete to repeatedy ant out the dyes followed by uresesive aloohol extraetions appoared to be best. However. the solubility of the dyes in commerelal alcohol (42) (43) prohlbits the use of the proeedure. It was necessary therePore to derelop individual proeodures.

4508 aample of Iapthol Iollow $\mathrm{g}$ we slurried with 50 co distilled water, set aside 24 hours to leach, and then racum flitered. Wh1s process was ropeated onoe. The cale wa then slurried with 150 co $7 \%$ by welght amonium oarbonate (Merok cos std.) In dist111ed water and leached 84 hours at which time 250 es $10 \%$ emmonim earbonate were added to thin the suepension. After 48 more hours leaching the mepension wes vacum filtered and the eale reslurried with 300 ec $10 \%$ amonlun earbonate and ot aside for 10 deje. Arter r11tering, the lat stop was repeated for 48 hours and 11 tered. The oake was dried 18 hours at $105^{\circ} 0$ and thon 48 houre at $95^{\circ} 0$ and $26^{\prime \prime}$ Ag vacuum to pemove any remaining water of erystellization as woll as $\left(2 \mathrm{LE}_{4}\right)_{2} 00_{3}$

The purifled dje was tested for oolub111ty at $26^{\circ} \mathrm{C}$ wieh, secording to Holmos (48), whould be 8.968 anhydrous aye /200es saturated solution. The dye dissolved to the extent of 
about $50 \%$ of this value thus indioating that the dye was probably the mono amonivie sulphonate form, 1.0., the hydroxyl did not form salt. The sodiun content of the dye was n1l as indicated by .0047 grams of ash obtalned from 1.8548 grams purifled dry samp10. The pH of a saturatod aqueous solution was 4.8 Instead of the uaual 8-8.5 for the rax form.

The purteled Napthol Yellow $S$ was dissolred in distilled vater, and HaOH (Horok) addod in comparatively small quentity. The released amonia (bound by the acld radicals) was removed by bolling $t 111$ no further odor could be detected. Th1s proeedure was repeated several times unt1l the $\mathrm{pH}$ of the saturated solution rose to 8.5. At this point a vory small amount of HaOH Inoreased the pHI to 11. The rosulting solution was coneentrated sufficiently for orystallization. The prealpltate was reorystallized from distilled water three more timos and then made up in a sandard distilled water solution. Drylng a five os samplo In vaeuuo as before gave a conoentration of . 217 moles /L (mol. wt. ammonlum salt = 358.20.).

A 80 gran sample of Amaranth was treated the same as the Yellow exeopting for the oautic treatment. It too showed approximately half the solubility specifled by Holmo (43) wich 1. $7.20 \mathrm{~g}$ anhydrous dje/10000 saturated solution. From $1.0907 \mathrm{~g}$ purifled Amaranth woro obtainod 0.2398 gram anh. The brown color of the sh Indloated Iron. Reashing with ruming nithe ne1d did not ohange the color nor the welght to 
any signifleant extent. Solution of the ash in aqua regie gave a brown solution whioh after diluting and filtering with subsequent noutralization with amonia gave the typloal ferrio hydroxide coagulum and water clear supernant Ilquid.

Large losses in purifloation nocossitated starting with a new raw samplo of 25 grams of Amaranth. This timo it was slurried with 6600 water and 3400 concentrated HOL (Grassel1) and after 24 hours leaching it was vaouum riltered. The flitrate was deop brown (not bright red) indleating removal of Iron wich was conflrmed by adding $2 H_{4}$ OR to give tho saine rosults as bofore.

The Amarenth preolpitato was reslurried with 3400 conoentrated HOL and 6800 water. The dyo showed some solubility, and therefore 3400 more conoentrated HCL were added. Aftor belag leached 8 hours the samplo was filtered and washed on the fllter with two $200 \mathrm{c}$ portions of 6 molar acld. The procipltate was reslurpiod with 50006 molar HCL and rer1ltored. The precipltate was washod on tho rilter with an addtlonal 50006 molar acld. By this time the dye showed remarkablo solub1lity. The proolpitate was dried by starting at $68^{\circ} \mathrm{O}$ and gradually ralsing it to $105^{\circ} \mathrm{O}$ during 24 hours. palltative anhing as before showed only a ralnt trace of $11 \mathrm{ght} \tan 0010 \mathrm{f}$ this time. The purifled Amaranth anplo was therefore dissolved in distilled water and noutrallzed with comentrated ammonla till a diatinet odor of 
ammonia porsistod. The solution was bolled unt1l all ammonia odor ranlahod. Bolling was continued unt1l tho solution becane syrupy. The resulting solution was diluted and cooled to give standard solution. Analysis as for lapthol Yellows $\mathrm{S}$ gave concentration of .133 moler (Amaranth molocular welght 1s 589, 60).

Potassium chlorlde was selected as the standard for "isoplest10" comparison of vepor pressure to be deseribed later. Purifioation consisted of dissolving $56 \mathrm{~g}$ potassium ohloride (Morok AOS grado) In 10000 distilled water, bolling to 5000 , and sotting aside for 24 hours to pormit reorgstallization. A standard solution was made up which gave on analysis a conoentration of 0.182 molar. (molocular welght of KCL is 74.55) 
B. APPARATUS 
Caloulation of osmotio pressure (44) from moasured rapor pressure and solution density was considered a most convonlont mothod of carrying out thi. Inrestigation. Prelindnary moasuromonts with 2 Bronsted-Riohards (45) type difforont1al vapor proasure oomparator showed that our apparatus was not rellable without a complleated tooknlque for continuously deteoting leaks. Consequently the leoplestle apparatus dorised by Robinson (48) and perfeeted by Seatohard (47) was deolded upon.

Th. Soatchard apparatur consistod of a brass vaourum desslestor 3-7/8" in dianoter 3-5/8" deep w1th a $3 / 16^{\prime \prime}$ wall Into whioh could be Inserted a brass pedental with $3-1 / 4$ " diameter top and $9 / 16^{\prime \prime}$ thiakmens and a $3 / 4^{\prime \prime}$ diamoter $1 / 2^{\prime \prime} \mathrm{hlgh}$ contered support. The pedestal could be bolted in place. The podestal has four $13 / 16^{\prime \prime}$ holes drilled $90^{\circ}$ apart. The oenter of each hole is $7 / 8^{n}$ from the conter of the pedestel top. The alze of the holes 1s wech as to permit an easy rit of four gold plated brass oups which are $2^{\prime \prime}$ hlgh and flared at the top allowing insertion of anug fitting brass oovers for welghing purposes.

The brass dese1eator was f1tted through a lead ganket soal to a $1 / 2^{n}$ thlok 4 " diamotor romovable brass top equippod with a conterally located whito wotal valve and dotechable 
serew nipple for attachmont to a Conoo Byreo oll vacuum puxp. The doslecator top oould be clampod in place by standing the assombly in a rootangular, rortical stool framo whioh had two thumb sorews at the top to permit olamping aotion.

4 -teol shart I1tted with a pulley was woldod to the top of the reotangular fram so that the complete assembly could be tilted at $45^{\circ}$ and rotated in a brass boaring wioh was so located that the dosiccator assembly would bo completeif Imorsed in a standard Sargent type thermoregulated water bath. The apeod of rotation was $24 \mathrm{rpm}$.

The prinolple of oporation 1s based on the 1sothorwal distillation of water from reglons of highor vapor pressure to those of lower rapor pressure unt1l the rapor pressure of all reglons (solutions) are equal. At equilibrium the solutions are sald to be "isoplestio" (meaning oquality or vapor pressure). Romoval of alr from the system oliminates orrors due to gasses dissolved in solution and also removes forelge moloowles from the distillation path between the gold plated oup containing the solutions.

The 1sothermal condition places a rather strenuoue apoolfioation on a standard Sargent bath. It was found noo- sasy to insert a low eurront relay into the normal oireutt so as to obtaln $20 \$ .00^{\circ} \mathrm{C}$ rogulation. Thls was considered adequate beokuse tho off-to-on time and vice rerse normally amounted to one minute or less and thus the mass of motal inrolrod could aet as thormal buffor. 


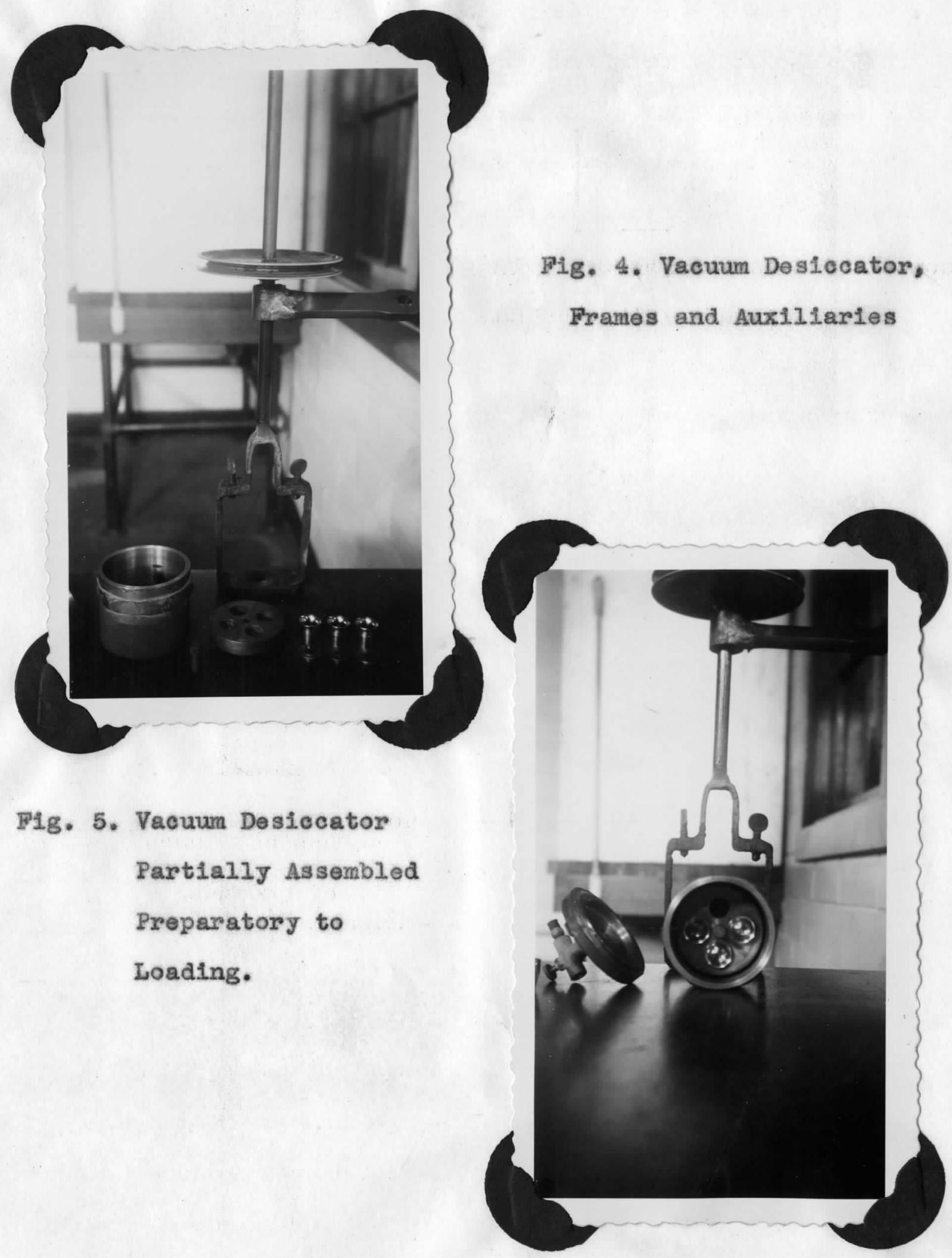




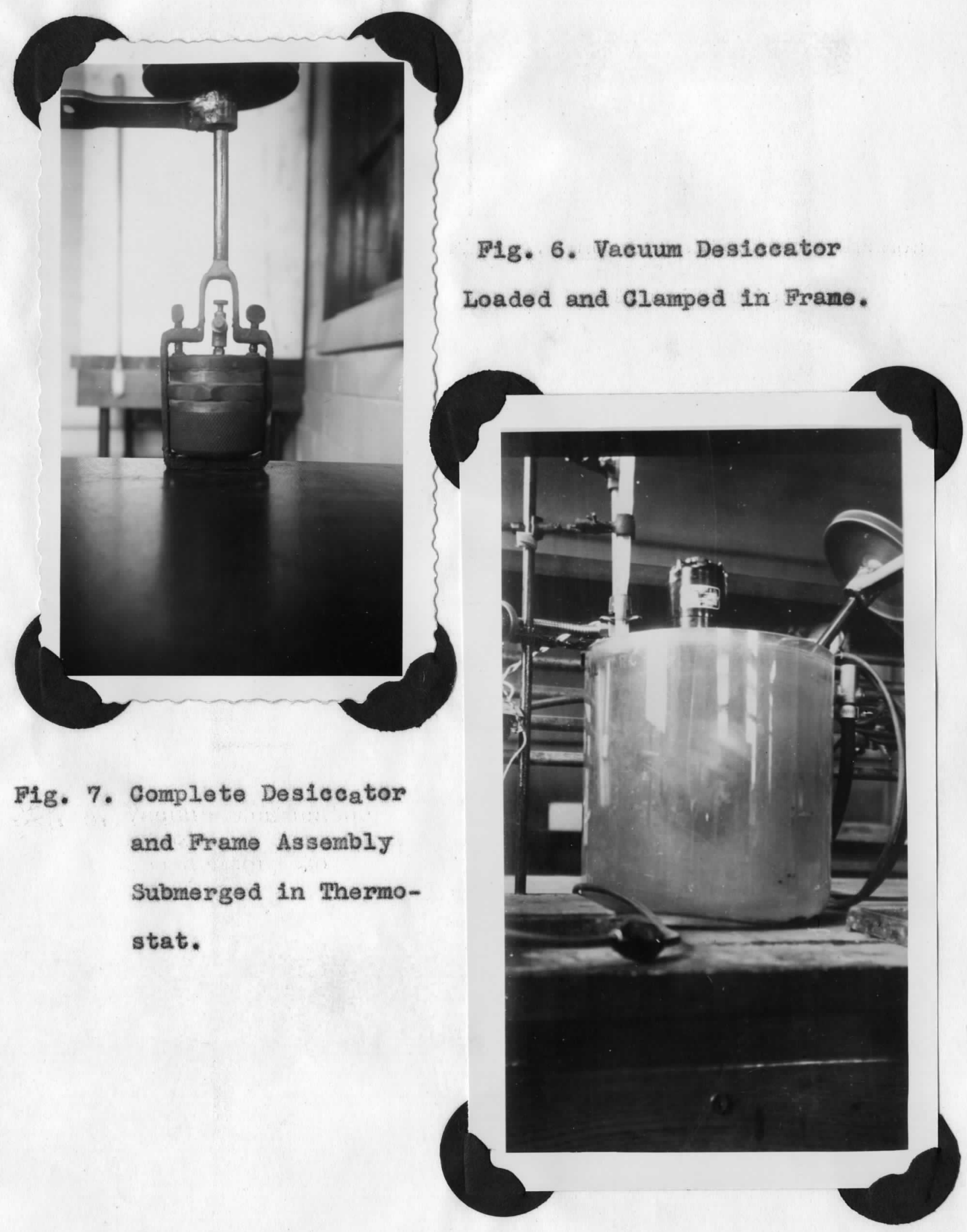




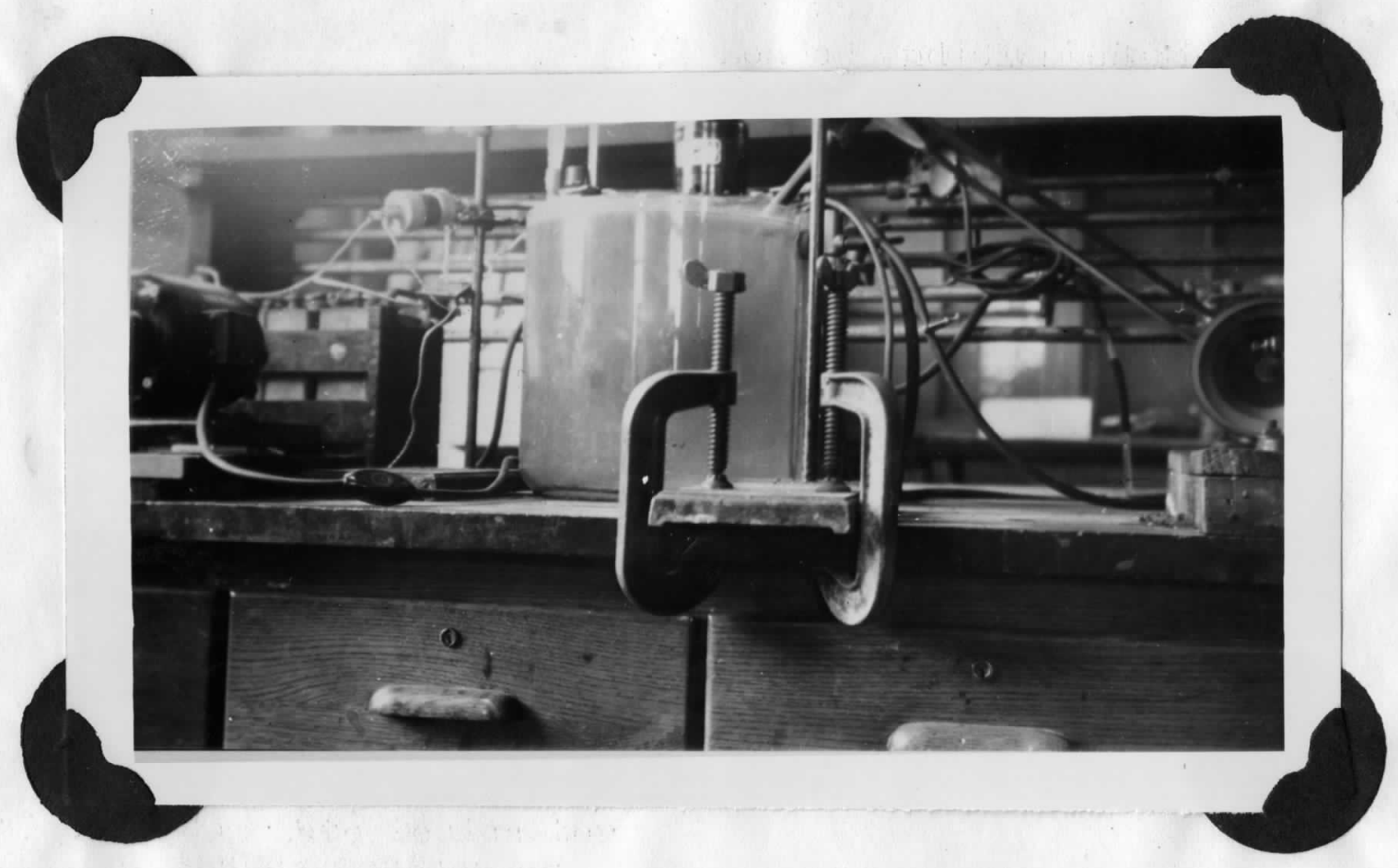

Fig. 8. Apparatus 
In order that most offeotive thomal contact betweon pedestal and gold plated oups would be assured, about 2000 of roL buffor solution was pleosd under the pedestal. Because of the $45^{\circ}$ t1lt, the buffor solution had easy acoss to the very mall space (If any) between pedestal and oup. Therwal contaot between solutions in the oups and the rapor phase was assured by partial Imoraion of a ting niohrome wire helioal in the solution of oach eup. The helloal has the added advantage that it inorcases atirring aotion through rotation, and inereases the exposed surface of solution thus decreasing the time required to reach oquilibrium.

The Seatehard 1soplestle apparatus and auxillaries are shown in F1gs. 4-8,

11 density determinations were made at $20^{\circ} \mathrm{C}$ using a 25 o0 glass pronomoter equipped with ground glass eap1liary and ground glass thermomoter. The wolghings were made on a ohalnomatio type grarimetrie balanee equipped with a rernior making poistble the reading of the fourth deoimal place. 
c. PAOCEDURE 
The donsity determinations wore oarried out in aecordanoe with the prosedure desoribed in almost ang elementary textbook of experimentel physical ohemistry and requires no further explanation than to mention that all solutions were made up rolumetriealiy from the atandard solutions and tho tare of the dry assembled pyohnometer was 18.4664 grams. It 1s also important to note that atandardisation of the prohnometer agalnst pure water gave a density of 0.9991 grama/oc. at $20^{\circ} \mathrm{O}$; wheroes the cocopted value, weording to Lange's handbook, 1s 0.9982 . Consequently all subsequent determinations wore corrested by multiplying by the ractor $0.9982 / 0.8991$.

The teohnique employed in the determination of rapor prossures was that desoribed by Seatohard. Before any runs were made the thormorogulated bath was standardized againat a new Becknan tjpe $0.01^{\circ}$ moreury thermometer which in turn had boen atandardised ualng a $0-100^{\circ} \mathrm{C}$ thonmomoter (Sargont) callbrated to $0.1^{\circ} \mathrm{O}$. During oach run the bath was constantly ohooked using both thermometors.

Prior to starting a run the dealecator assembly. Inoluding three of the gold plated oups, nichromo holleals, and caps, was oleaned thoroughly and drlod. Bach oup, holloal, and oap assembif were givon numbers 11 was used oxelusively for xol solutions, \#2 for Mmaranth, and \#3 for Hepthol Yollow S. After cech assembly was tared, monured rolume of the 
appropriate solution was placed in oach oup, and then the assemblies were Immodiately rowolghod. Fuch solution was provlous2y prepared from its standard toek solution using a predetermined dilution ratio wioh was standard for all oolutions made up for the partioular run.

The deslocator was prepared by placing in it 17-8000 of a KoL buffer solution of approximately the ane coneontration as that in the kOL oup. The pedestal was inserted and bolted in place and all sealing surfaces liberally coated with vecuum sealing grease. At this point the oup were inserted, the onps removed, and the desiocator top elamped in place as rapidly as possible. The desieantor was oveouted for about ten minutes with gentle ahaking to asist in bolilng out the lest traces of alr. The racum valve wes then olowed and the deteohable nipple roplaeed w1 th brasa plug.

the complete assumbly was rotated in the water bath; and after equilibrium had beon reached, the procodure was repeated in reverse order. A1 three oupa were eapped as soon as the desiecator was opened, rinsed with distilled water, dried thoroughly, and immediately welghed. The buffer solution was remoasured to cheok for leaks, sterting rolume or 1ess being the only bals on whleh a run wes aceepted for further consideration.

The tine required for equilibxiun was determined from a fow preliminary mun. Ioss than one mi11111tre of so- . Iution in the oup always gave negligible change after three 
days and up to 16 days even in the ease of more dilute solutIons. Throe dajs was theroforo adoptod as tandard. 
D. RisULms 
A prelininary examination of the thermodymamic equation (44)

$$
p=\frac{\text { AT }}{V_{1}} \text { in } \frac{p_{Q}}{P_{0}\left(p_{0}-p\right)}
$$

where

$$
r_{1} \cdot \frac{u}{1000\left[1-0 \frac{a x}{20}\right]}
$$

and

$$
\begin{aligned}
& H \text { : gram moleoular welght of the soltant } \\
& \rho=\text { density of the eleotroljte solution at the } \\
& \text { quilibrium coneentration o, moles/1 } \\
& \frac{d P}{d t}=\text { rate of change in solution dene1ty with ahange }
\end{aligned}
$$
rerealed that $1 t$ would bo most convenient to have the mathemat1eal expressions for both $\left(p_{0}-p\right)$ and $P$ in terms of the concentration, 0 .

Graphical analyal of the density-determinetions gave stralght line relationmips when $\rho$ wa plotted against 0. 
The equation of these stralght lines were

$$
\rho=.9982+.27120 \quad \text { (Amaranth } 0 \leqslant 0 \leqslant .233 \text { ) }
$$

and

$$
P=.9988+.20060 \text { (Napthol Yellow S } 060 \leqslant .298 \text { ) }
$$

A similar plot of the data for KOL from Lange (48) handbook gave

$$
P=.9982+.04730 \quad(0 \leqslant 0 \leqslant .272)
$$

A aurrey of the 11terature on vapor pressures of d1Iute equeous ICL solutions at $20^{\circ} \mathrm{O}$ revealed that the data of Lorolaco, Fraser and Soase (40) wore most satiafactory. Tho -quation

$$
p_{0}-p=\frac{1+.18960}{1+1860}
$$

was derlved by the mothod of simultanoous equations and gave a rory eatiafactory rit.

$$
\begin{aligned}
& \text { As a corrollery of equations } 15,26 \text { and } 17 \\
& \text { x by wt. Amaranth }=\frac{217.40}{3.681+0} \\
& 4 \text { by wt. Hapthol Yollow } s=\frac{178,60}{4.976+0} \\
& \text { क by wt. } \mathrm{rol}=\frac{157.60}{21.20+6}
\end{aligned}
$$

As a corrollary of equations $15,16,17,19,20$, and 21 and the faot that the concentration rolume produot is a constant for any one solution both bofore and after an 1soplestio determination it is possible to derivo the following simplirled expresglons (see appendix) for equilibrium ooneentratione: 


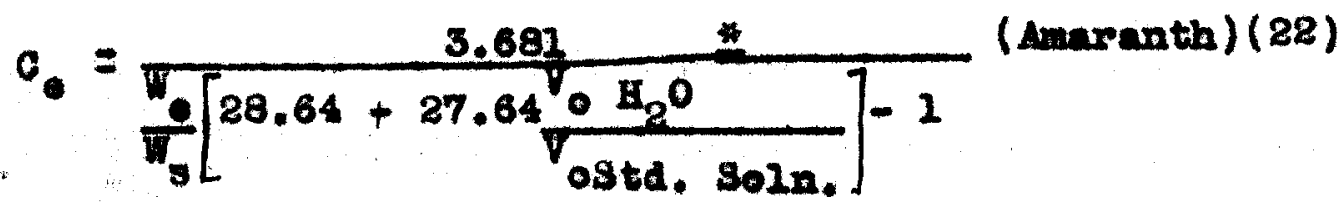

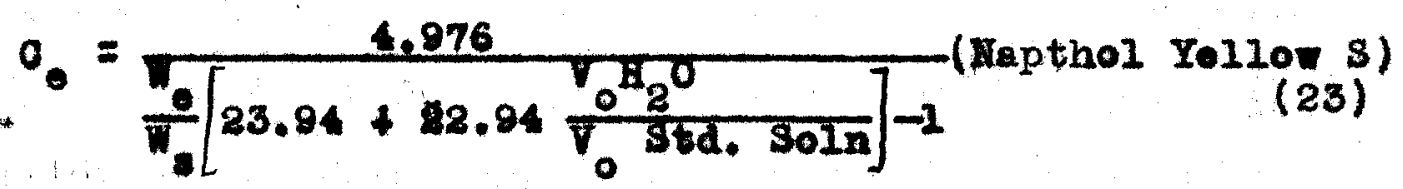

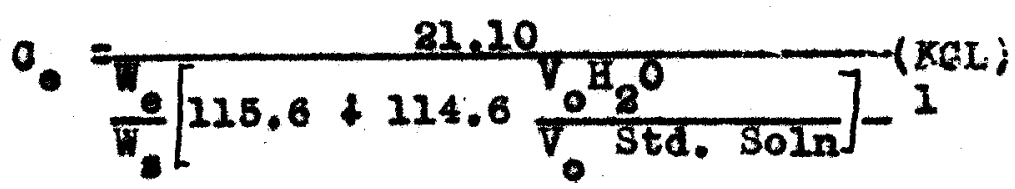

where

$$
\begin{aligned}
& w_{.}=\text {wt. of solution placed in the oup } \\
& \text { W. wt. of solution at equilibrium } \\
& v_{0}=\text { volume of the constltuont used in making } \\
& \text { up the solution from which wa withdram. }
\end{aligned}
$$
tlons horein oonsidered (50)

$$
P=3817.0-3068.6 \log \left(17.535-\left(p_{0}-p\right)\right)
$$

whon the values of tho constants are subatituted beoause in every oase $\rho=0.9982+$ slepe* $c_{e}$ and $\frac{d \rho}{d C_{\rho}}=$ alope thus roducing $\rho-o_{0} \frac{d P}{d C_{e}}$ to the constant, 0.0982 .

The exnot procedure for computation of the results of any one 1sopiestio determination is roduced to throe steps whloh are (a) the computation of equilibrium conoentrations using equations 22,23 , and 243 and (b) the computation of $P_{0}-p$ using equation 18 comblnod with the value $o_{0}$ computed from equation 24 and (e) the oomputation of the omotie prosaure using equation 25. The caloulated raiues of $c_{e}$ and $p_{0}-p$ for each mun are prosented in Table 3 . They are also plotted 
In F1gs, 9 and 10.

The actual plots and oalowlated values of equation 25 are not Included beoause any conclusion derived from them 1s also oqually obvious from PIgs, 9 and 10. Bquation 25 would serve only to modify slightly the contour of ourved portions of the figure but would leave horizontol flats unaffoctod. In ithor caso it is the flats in which one is. primarily interested. Henee all subsequent disoussion portalning to osmotio pressure refors to Figs. 9 and 10 with equation 25 being understood. 
Table III Caloulated Bquilibrium Coneentrations for Isoplest10 Solutions

Run Ho. Duration (days)

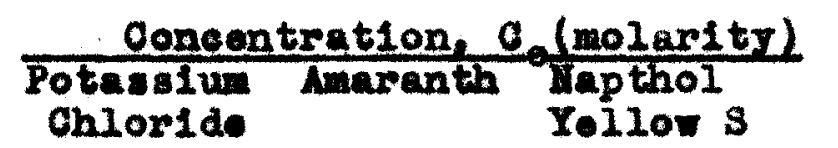

YoIlow s
1

2

3

4

5

6

7

8

9

10

12

14

15

16

17

18

19

20

21

28

23

24
2

3

16

3

3

3

3

3

5

4

3

3

3

2

3

3

3

3

5

3

4

3

$$
.017
$$

.185

.092

.077

.142

.135

.087

.078

.078

.075

.167

.154

.135

.115

.165

.052

.048

.070

.068

.060

.053

.098
.013

.168

.078

.063

.127

.122

.076

.065

.066

.065

.161

.145

.123

.101

.159

.038

.036

.056

.055

.048

.042

.087
.020

.217

.086

.073

.155

.244

.084

.076

.076

.073

.190

.170

.142

.118

.185

.046

.041

.058

.059

.052

.046

.090
Vapor pressure lowering

(mm $\mathrm{Hg}$ )

.0104

.1064

.0542

.0454

.0825

.0777

.0514

.0462

.0460

.0444

.0069

.0894

.0785

.0670

.0950

.0302

.0885

.0410

.0401

.0355

.0315

.0572

Hote: Huns 11 and 12 wore defoetive. 


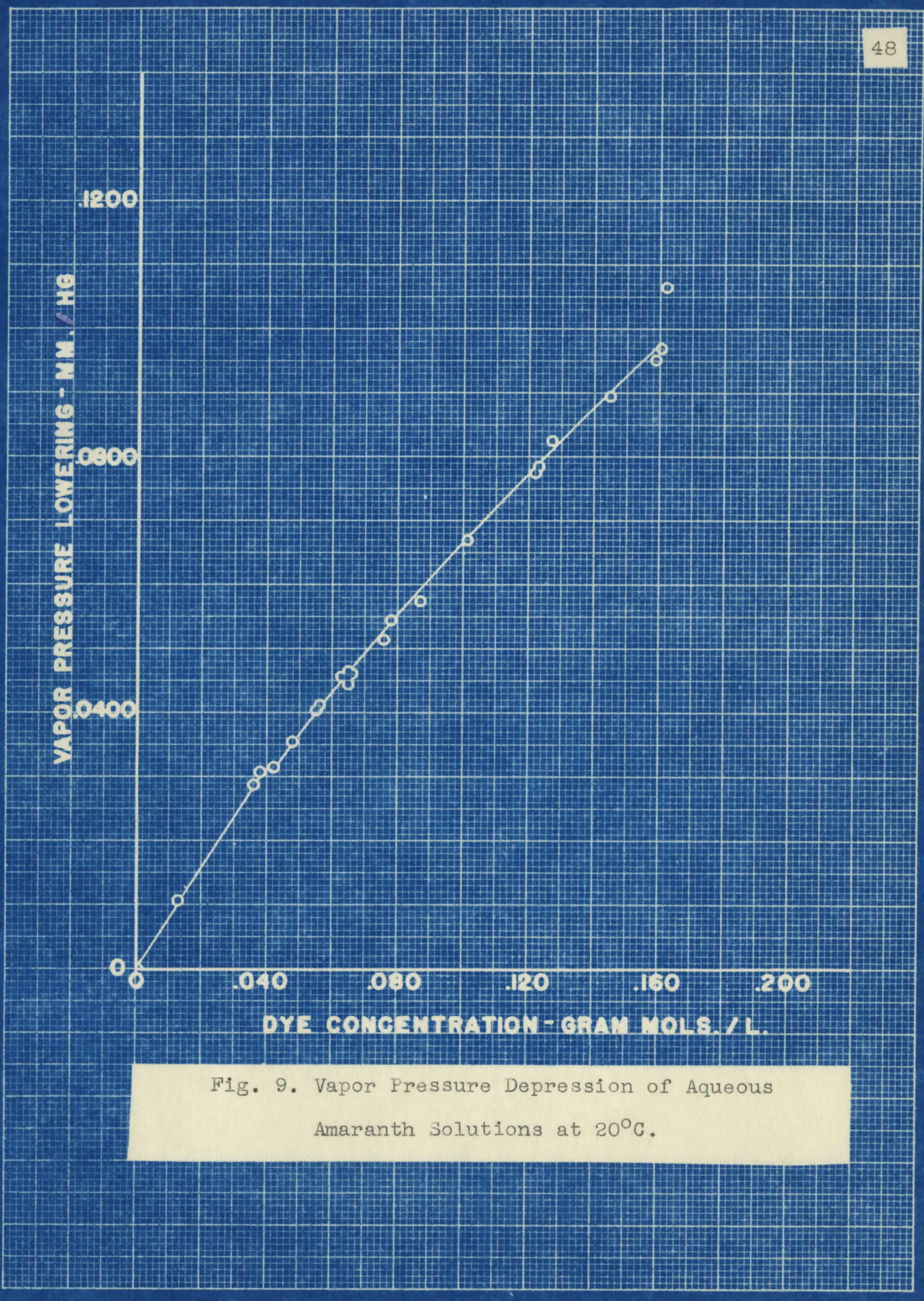




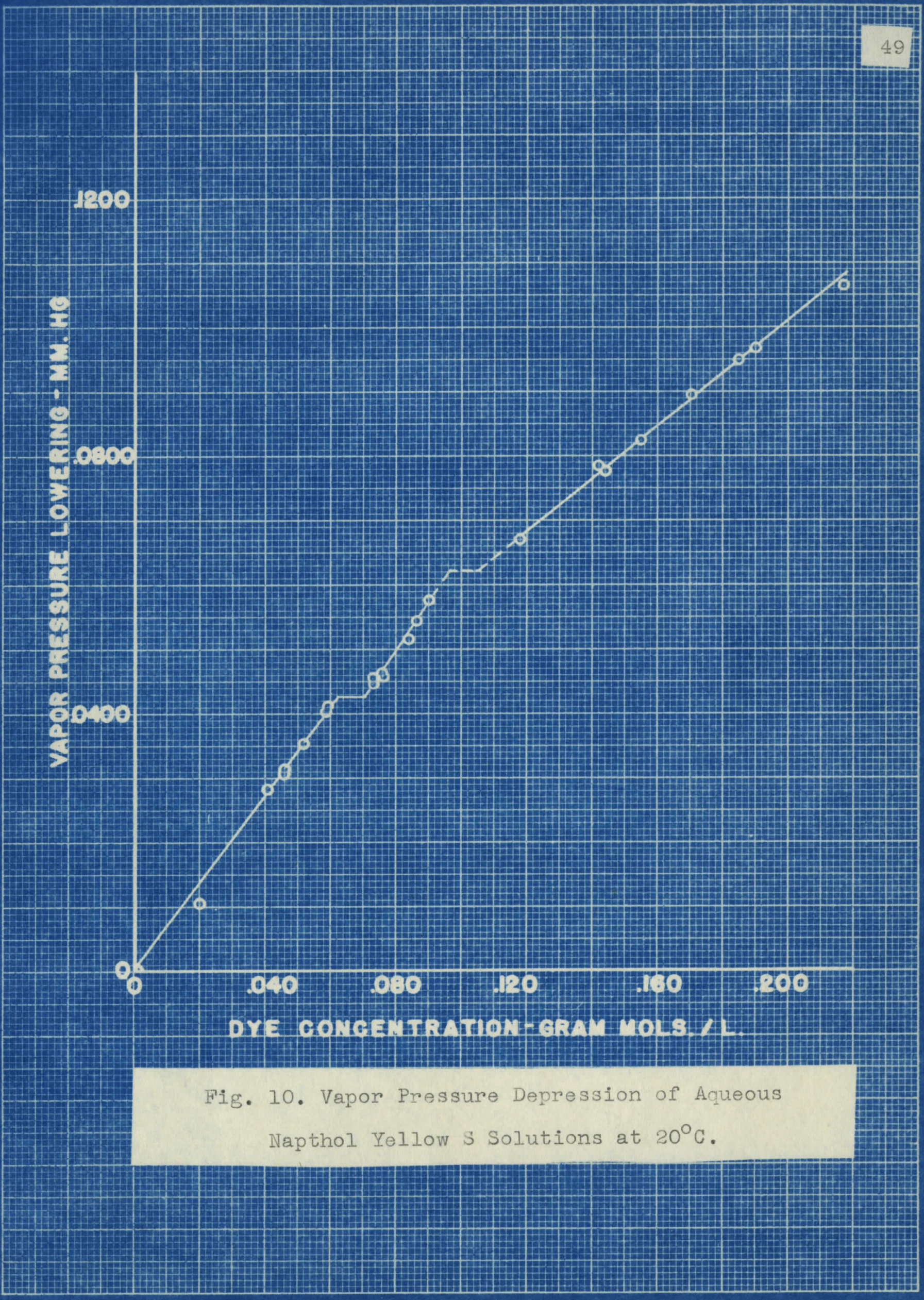


E. Drscussion 
Inab1lity to oontrol a thermoregulated bath at $20^{\circ} \mathrm{C}$ during the summer months when tap water is considerably warmer, made it nocessary of ther to add more equipment or to discont1nue operations. The latter alternative was ohosen considerIng that the avallable data wore unusually consistent and gave a postive indioation of the discontinuitios which wore or course expoeted. This procedure nocessitated estimating the portions of the ourves over the discontinuities. The estimates have beon show as riats ainee in tro ases out of the three it is noxt to impossible to draw in ang reasonable continuous estimate which would not have at least one point of zore slope. The ordinate of the llats wore arbitarily seleoted as the arithmetio average of the ordinates of adjacont deta points.

The elat in the case of smaranth might be questioned because there are only three points on the lower portion of the eurve to support olain to the lower concentration boundary of the 1lat. This question appears unfounded, howerer, wen 1 t 1s considered that all data points around the flat are not only self consistent but are based on the same sample thus eliminating many possible sources of error which might bo interpreted to acoount for the phenomonon. Assuming the validity of the flats one resorts to 
the phase rule for their interpretation. It is immodiately obvious that they represent the coexlstence of two phases whloh are in all probability 1sotrople solution and mesomorphous or 11quid orystalline solution. Mesomorphlsm is a presupposition based on the mioroseoplo oharacter of these solutions.

According to the theory proposed the coexiatence of the two phases is the diroct result of a maximum in osmotio pressure $\mathrm{h}_{\mathrm{a}}$ ing been obtained. That this is true is conrirmed by P1gs, 9 and 10, whorein the rlats would ropresent the natural course of erents. In order to test the ability of the theory to predict the occurrence of the lower ooncentration flats or split Into two phases, one mast again refer to equat1on 11.

Por Amaranth whose formula is

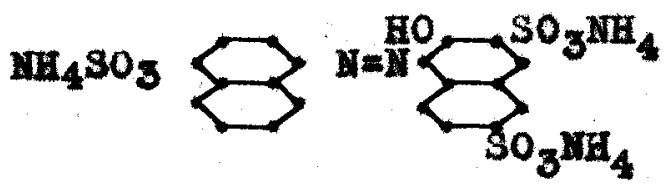

$z_{1}$ is 3 and $z_{2}$ 1: 1 and thus for pure aqueous solutions at $20^{\circ} \mathrm{C}$

$$
\theta_{1}=0.054 \text { molar (apparent) }
$$

Th1s agrees remarkably well with the range $0.038-0.042$ for the slat as read from F1gs, 9 and 10.

Inpthol Yollow $S$ has the formula

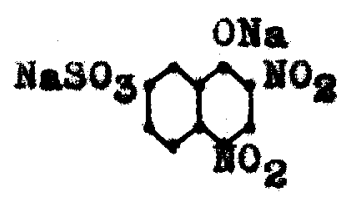


whore $z_{1}$ is $2, z_{2}$ is 1 and

$$
c_{1}=0.243 \text { molar (apparent) }
$$

From FIgs. $\theta$ and 10 the range of concentration is actualiy 0.062 to 0.070 whlch represents rather poor agreement. This raot might at rirst lead to question of purity or some other faotors, but experionee ahows that the findings are valid. The rosults can be vorified for both dyes by application of tholp aquoous solutions to glass and allowing them to become more coneentrated through normal ovaporation. The surface orlenting offoct of gless on the mosophase oan be detoeted in polarizod light. In the oase of Amaranth the surface effoet is always detectable. Inis is not true of the Yellow, howeror. Yollow solutions moro conoentrated than 0.1 molar do not show the offect. Solutions less conoentrated than about 0.1 molar do show the effect only if eraporation is falrly rapid.

All the raots oan be bost explained by the schomatic diegrams, Figs. 11 and 12. For both dyes the drying operation prooveds from left to right across the diegrams at approximately the $80^{\circ} \mathrm{O}$ level (Iower quarter of diagram). As the comon linit of solubility (IIno onclosing right hand shaded r1eld) 1s orossed under normal drying conditions the smaranth apparently gires a superseturated mosophase, whoreas the Yollow orystallizes out. In the oase of rapld ovaporation Amaranth acts the same as bofore, but the Yellow producen a supersaturated mesophase only when the starting solution is 
suffieiently dilute to oross the mesophase region.

The lack of good agroement botwoen thoory and oxperiment in the case of the yellow is also not too disturbing when cognizanos is taken of the fact that the thoory rooognizes no differences in molecular oonstitution. That this factor is operative 1s orldenoed by the following quotation from Vold (12):

Por ach mesomorphlo forms to exlat the molooule must contain groups of contrasting Intermoloowlar forces so that a tomperature range exist: within which the rlolenes of thermal agitation is large onough to orercomo somo but not all of the mutual attraetlons and repulalons which at a lower tomperature load to the arrangemont of the molooules In regular orystal lattioe. Purther, those groups mut be so loosted that suoh a partial molting pormita a random diatribution in some direction: without disturbing the rogular periodio spacing in other direotions.

Bron though Mmarenth and Mapthol Yollows $S$ are both sulpho salts and the yellow would be expected on this basis to show the same good agreement as Amaranth, the fact that the jellow diffors in that 1 is is a nitro compound oan not go without rocognition. It appears, therefore, that the thoory is highly satiafactory provided 1t is not applied indiscriminately. 


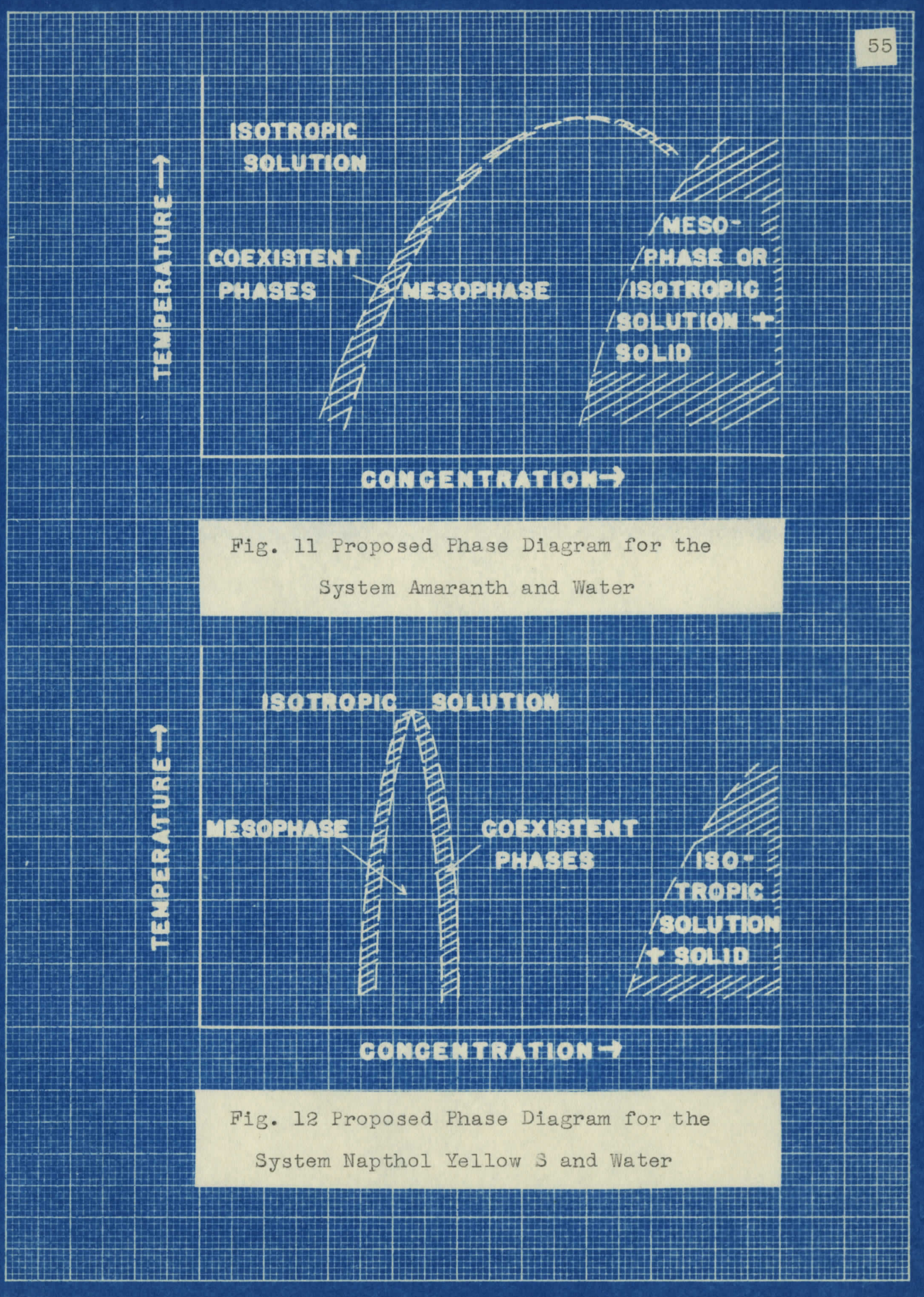


SULTARY ATD OOMOLUSIOMS 
A study of the osmotlo beharlor of aquoous Amaranth and Napthol Yellow s solutions at $20^{\circ} \mathrm{C}$ has beon oarrled out using the Indireat mothod of moasuring the concentrations of 1soplestio solutions. Those results in confunotion with othors from the 11terature have been used in testing the theory proposed that 11quid orystaline mesophases are the direat result of a maximum in osmotic pressure wich can be predieted from the Dobye-Huckel theory flrst approximate equation oxactly the ame as unipoler coecervates wore prodicted by Langmulr.

It has been found that both dyes do exhibit phase soperation, but the Hapthol Yollow 3 exhiblts the phenomenon over narrower range of conoentration than does the Amaranth.

All cases inoluding those from the ilterature agreo remarkably woll with the theory proposed with the excoption of the case of Napthol Yellow S. In the latter esse the differonoe betwoen fact and theory has boen rooonolled based on difforenose in molocular constitution.

It has boen conoluded that the theory is highly satisfactory prorided it is not used indisoriminately. 
LITERATURE CITED 


\section{Periodioal:}

(3) Ornstein, L. S. and Kast, W., Trans Paradny Soo., 29, $831-44$ (1933)

(4) Lawrenoe, A. S. O., Roy. Morosoop. Soo., 58, 30 (1938)

(6) Symposive; Trans. Faraday Soo., 29, 899-1056 (1933)

(7) Bungenberg de Jong, H. Q. and Kruyt, H. R., Kollold Z., $50,39-48(1930)$

(8) Dobry, the, A,, J. Ohim. Phys., 36, 102-10 (1939)

(9) Langmulr, I., J. Ohem. Phys., 6, 873-96 (1938)

(10) Dobje, P. and Huokel, B., Physik, Z., 25, 97 (1924)

(11) Zoohor, H, and Bifetein, V., Z, physik, Chem., Abt. A, $142,177-85$ ( 1929 )

(12) Vold; H. J., A. Chem. Soc., 63, 1487-32 (1941)

(13) Vold, R. D. and Vold, Y, J., J. An. Chem, Soo,, 61, 37-44 (1939)

(14) Vold, R, D, and Porguson, R. H., J, A., Chom, Soo., 60, 2066-76 (1938)

(15) MoBain, J. W, Yold, R. D. and Friak, M., J. Phya, Chom,, 44. 1013-24 (1940)

(26) Vold, R. D., J. Fhys, Chem,., 43, 1213-31 (1939)

(17) Vold; R, D., Reivere, R, and MoBaln, J. W., J. Am, Chem. Soc.. 63, 1893-6 (1941)

(18) Conlok, E. and MoBain, J. W., J. Am. Chom, Soc., 68, 683-5 (2946)

(19) Zoohör, H. and Copor, X., Z. Physik. Chon., 132, 295 (1928)

(20) Gaubert, F., Oompt. rond., 200, 679-80 (1935)

(81) Ib1d, 198, 951-3 (1934)

(22) Ib1d, 197, 1436-8 (1933)

(23) Ib1d, 163, 392-4 (1816) 
(24) Branner, Fr., Mord. Kemikermode, Forh. 5, 207-9 (1939)

(25) Sandqvist, H., Kollo1d Z,, 19, 113-21 (1916); J. Ohom. Soc.. II, 110, 556

(26) Sandqrist, H., Bor. 48, 2054-5 (1915)

(27) Sandquist, H., Ark17, Kaml, Min. Gool., 7, \#2 (1917)

(28) Sandqv1st, H., Ark17. Koml, Min, Gool., 6, \#13 (1917)

(29) Sandqrist, H., Ber. 50, 774-7 (1917) through J. Chem. So0. I, 112, 552

(30) Sandqrist, H., Chem, Absts,, 10, 715 (1915)

(31) Ib1d, 11, 1350 (1816)

(32) Ib1d, 12, 807 (1917)

(33) Sandqv1st, H., Ber. 53, 268-71 (1980)

(34) Choah, J. C., J. Chem. So0., 113, 707-15 (1918)

(37) Van Rysselborghe, P., J. Am, Ohem. Soc., 65, 1249 (1843)

(39) Sandqriat, H, and Hagelin, A., Ber, 51, 1515-26 (2918)

(40) Lohmann, 0., Ann. Phye1k., 55, 81-102 (1918)

(41) Heale, S. M., Am. Dyestuff Roptr., 23, 109-11 (1934) .

(42) Holnos, W. O., Stain Teoh., 2, 68-70 (1927)

(43) Ib1d, 3, 12-13 (1928)

(45) Bronaterd and Rlchards, J. Am. Chem. Soe., 50, 3028-36 (1988)

(46) Robinson, J. Am. Ohom. Soa., 56, 1830-36 (1934)

(47) Seatohard, A., Hamer, W, J. and Wood, S, B., J. Am. Chom. Soc., 60, 3061-70 (1938)

(49) Lovelace, B. F., and Soase, V. B. and Frazer, J. C. W., J. Am. Chom. Soo., 43, 202-10 (1981)

(52) Lawronce, A. S. C., Trans. Paraday. S00., 29, 1008-15 (1933) 
(53) Rinnie, F., Trans. Paraday. Soc., 29, 1016-38 (1933)

(54) Mods1ejorak11, A., Kryat. Kin., 52, 1-10 (1813)

(55) Vold, M. J., J. Am. Ohem. Soc., 65, 465-8 (1843)

(B6) Soholbe, G, and Kandlor, L., Naturwiseonsohafton., 26, 412-13 (1938)

(57) Shopperd, S. B., Solonoe, 93, 42-3 (1941)

(58) Soholbe, G.. Kandler, L. and Eoker, H., Haturus sensohaften, 25, 75 (1937)

(59) Jollej, E. B., Nature, 139, 631-2 (1937)

(60) Soholbe, G., Mare1a, A, and Boker, H., Naturwissensohaften, 25, 474-5 (1937)

(61) Hoppe, W., Kollo1d Z., 101, 300-5 (1942)

(62) Zooher, H., Z, physik. Chem., 98, 293-337 (1921)

(63) S segrar1, A., physik. Ohom., 212, 295-316 (1924)

(64) Zoohor, H,, Z, anorg. allgom. Chom., 147, 91-110 (1925)

(65) Ostwald, Wo. and Waltor, R., Kollo1d Z., 76, 291-313 (1936)

(66) Papkova, T. P., - Kw1tzel, Kollo1d., 69, 57-65 (1934)

(67) Ib1d, 71, 165-8 (1935)

(68) Hatachek, B. and Jane, R. S., Kollo1d Z., 39, 300-13 (1926)

(69) Froundlioh, H., Sohustor, C, and Zooher, H., Z physio. Chom., 105, 119-44 (1923)

(70) Krause, G. A., Brit. pat. 483, 221 Apr11 7, 1938

(71) Kondo, T., Z. Wlas, Phot. 31, 153-67, 185-99 (1938)

(72) Kuhn, W. and Erdos, G., Xollo1d Z., 70, 241-61 (1935)

(73) Zooher, H., and Jacoby, F, B., Kollo1dohem, Be1herte, 24, $365-417$ (1927) 
Booke

(1) Lobman, 0., Molokular Phya1k.", Lo1pzig (2888)

(2) Mriodol, O., Ohapt. III of Aloxandor, J." "Oollold Chemistry", Vol. I. IY, The Chomleal Catalogue Co.. Ino., (1986)

(5) Vorlander, D., "Chemlsohe Kr1stallogrephie dor Flusaigke1ten", Unirersity Hall a.d.s. (1924)

(35) Gotzan, F. H, and Danials, F., "Outilnes of Theoretical Chemletry", 5th. edition, p. 479. MY, John w1ley and Sons, (193i)

(36) Lowls and Randall, "Tho Thermodynamios and the Free Mnorgy of Chemieal Substanoes", p 373, IY, MoOraw H11I Book Company (1923)

(38) International Orit1oal Tablos", Vol VI, Pg. $78 \mathrm{MY}$, MoOraw Hill Book Gompany. Ino. (1929)

(44) Glasstone, S., "Textbook of Phys10al Chemlatry", and. edition, pp. 669-70 IY, D. Van Hostrand Company, (1946)

(48) Lange, H. A., "Handbook of Chomlstry", 6th. edition, p. 1291 Sandusky, Oh10, Handbook Publishors, Inc., (1946)

(50) Lange, H. A., "Handbook of Chemlatry", 6th, odition, p. 1444 Sanduaky, Ohlo, Handbook Publlshors, Ino., (2946)

(51) Freundlioh, H., "How Coneeptions in Colloldel Chomistry", Pg. 108 IY, Dutton and Company, (1926) 
APPEDTX 
Liat of Symbol.

os Oub1e contimotor:

$a_{1}$ Molar concentration at the $1^{\text {th }}$ stage or for the $1^{\text {th }}$ mole

D Dieleotric constant of solvent

- Unit or eloctrostatio aharge (osu)

8 Orams

9 Oamotio coeffiolent (dimensionless)

k Boltzman constant, $R / M$, where II is the Avogadro number

1 Liter

4 aram mole weight of solvent

$H_{2}$ Oran mole wolght of solute

Millimoter:

n Cras moles

I Hormality expressed as gram equivalonts por liter Arogadro number

$n_{1}$ Iumber of gram lons of $1^{\text {th }}$ specie in a ouble centimeter

$P$ Osmotio presaure in consistent units

p Vapor pressure (oonsistent units). Subseript soro indieates pure solvent

R Gas constant (oonsistont units)

I Absolute tomperature $\left(\mathrm{K}^{0}\right)$

$\nabla_{1}$ Partial molar volume of solvent refored to solvent in

V Volumo (oubio centinoters)

$w_{1}$ Gram wolght as $1^{\text {th }}$ stage

$\lambda$ The Debjo distanoe (consistent units) 
P Density (grans/00)

$0,8,0$, Subscripts refering to the speciflo stagos of run, namely, preparatory, atarting and at equilibrium respectively. 


\section{Glossary}

Anisotropio Having directional properties

Anomalous Abnormal

Blpolar Possessing both positive and negat1ve chargod part1010s

Coacervate Solvated mieolles which have collooted into a 11quid aggregate

Coscervation The process of dividing into a concervate phese and supernant liquid phase

Common linit The nomal solubility as determined by standard of solubility mothods

Complex coae- Contalning positive and nogatire solvated orvato mioelles (bipolar conervato)

Orystallino Soe 11quid oryatalino

11quid

Gegenion:

The German equiralont for counter lons or lons or opposito oharge

Homopolar Having one type of charge

Indiatinot Two phases, the one being finoly dispersed in phase sepera- the othor

tion

Isop1est10 Equal vapor pressures

Isotrop10 Wi thout direational properties

Llquid erys- Liquid possesalng some propertios of orystal talline

Iyoph1110 Having affinity for solvent

Mosomorphous Being intermediate betweon orystal and liquid (IIquid orystallino)

Hosophase

An Intermodiate phase, in this ease the 11quid orgatalline or anisotrople liquid phase

Motastabl. Temporarily oxistont (unstable) 
Wolar(apparent) Mold/1 concentration caloulated from formulae involving lonle trongth

Domat1e

A type of liquid orgstal with thread like strueture

Simple coser- Containing solvated mleelles of 11ke charge rate (unipolar concorvate)

Smoot1e

A type of liquid orystal with soap like strue ture

Streaming dou- Rofracting power whloh due to flow differs in blo rofraotion two direotions at right angles to each other

Swarm An ordered arrangoment of partieles (probably molooulos) in a ilquid mass

Tactold

Coacervate whioh spontanoounly assunes a comon orlentation resembling a swaxm

Th1xotrop10

Fulds wos visoosity is sonsitive to touohing or stirring

Unipolar cone- Solvated micelles of 11ke charge whloh hare ervate colleoted Into a llquid ageregato 
Table IV Density of Aqueous Amaranth Solutions at $20^{\circ} \mathrm{C}$.

Conoentration

(molarity)

.000

.005

.011

.015

.022

.033

.035

.044

.053

.055

.057

.066

.070

.078

.077

.088

.091

.099

.100

.109

.111

.129

.128

.138

.138
Not weight of solution

in pjonometer (g)

24.9789

25.0148

$\$ 24.9990$

25.0838

$\$ 25.0838$

$\$ 25.1684$

25.2176

$-25.2400$

25. 3374

425.3253

25.3664

25.4242

25. 4527

25.4882

$-25.4257$

25.5703

25. 5876

$\$ 25.6669$

25.6563

25.7248

25.7384

25.7878

$\$ 25.7827$

$\$ 25.8658$

25.8822
Density

.9982

.9997

.8990

1.0084

1.0024

1.0058

1.0078

1.0090

1.0286

1.0121

1.0137

1.0160

1.0172

1.0186

1.0161

1.0219

1.0226

1.0233

1.0853

1.0880

1.0286

1.0306

1. 0304

1.0337

1.0343

Lote (4) ralues rejected due to alr bubbles. 
Table V Density of Aqueous Napthol Yellow s Solutions at $20^{\circ} \mathrm{C}$. Conoentration (molarity)

Het wolght of solution

in pjonomoter ( $\mathrm{g}$ )

Density

.018

25.0706

1.0019

.036

25.1640

1.0056

.054

25.2555

1.0093

.072

25.3470

1.0189

.000

25.4369

2.0165

.208

25.5388

1.0205

.126

25.6224

1.0239

.145

25.7113

1.0275

.163

25.8006

1.0311

.181

25.8901

1.0347

.189

25.9811

1.0383

.808

26.0249

1.0400

.217

28.0676

1.0418

.225

26.1056

1.0433

.243

26.1783

1.0462

.253

26.2438

1.0488

.269

26 . 3801

1.0519

.286

26.3966

1.0548

.898

26.4521

1.0571

.380

26.8833

1.0720 
Table VI Starting and Bquilibrium Welghts of Solutions

Run Starting welrht (R)

Xo. Potaselum Ameranth tapthol Ohioride 101100 8

.9967

$1 \quad 1.0014$

$8 \quad 1.0324 \quad 1.0266$

$3 \quad .5100 \quad .5208$

$4.8066 \quad .4458$

5

6

7

6

8

10

28

14

18

16

27

18

19

80

21

29

83

84

.9906

1.0462

.5170

.6438

$.5134 \quad .5122$

.5314

.5646

.8588

.9568

.0602

.5125

.5615

.6097

.6963

.5538

.8179

.6671

.5068

.4996

.6067

.5852

.6486

.6102

.3847

.4556

.4048

.5159

.4640

.5816

.5288

.7253

.8254
Roull1brive welght (a)

Potaseiv Amaranth Iapthol

Ohlorido

Yolion 8

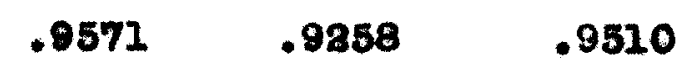

1.0258

.8496

1.0414

.5068

.4458

.6458

.6067

.5481

.7587

.5314

.4305

.5673

.5646

.4460

.6102

.0589

.700

1.0268

.9568

.8281

1.1342

.8608

.8220

1.1400

.9950

.8815

1.1795

.5615

.4253

.6185

.6097

.4701

.6859

.6863

.5538

.8282

.8172

.6671

.9761

.5727

.4380

.6360

.6067

.5858

.8158

.648

.6102

.9034

- 4469

.3947

.6348

.4586

.4048

.6326

.5159

.4640

.7153

.5816

.5268

.8154

.3181

.2588

.4284 
Table VI Con't.

Dote: Composition of solutions plaoed in oup for than 1 was. 0.5 volumes tandard solution to 5 volumes water. Run 2 was standard solutions. Run 3 was balf and half by rolumo, and it was not ohanged for Run 4. Fun 5 was 2 rolumes atandard solutIon to 0.5 rolumes water and was not ohanged for Runs 6-11. fiuns 11 and 12 were rejected for defeots and leaks. Aun 13 was standard solutions whioh were not changed for Runs 14-17, Thn 18 was 1 standard solution to 2 water and was used through kun 24. 
Table VII The Lowering of the Vapor Pressure of Water at $20^{\circ} \mathrm{C}$ Produced by Dissolved Potassiun Ohloride (49)
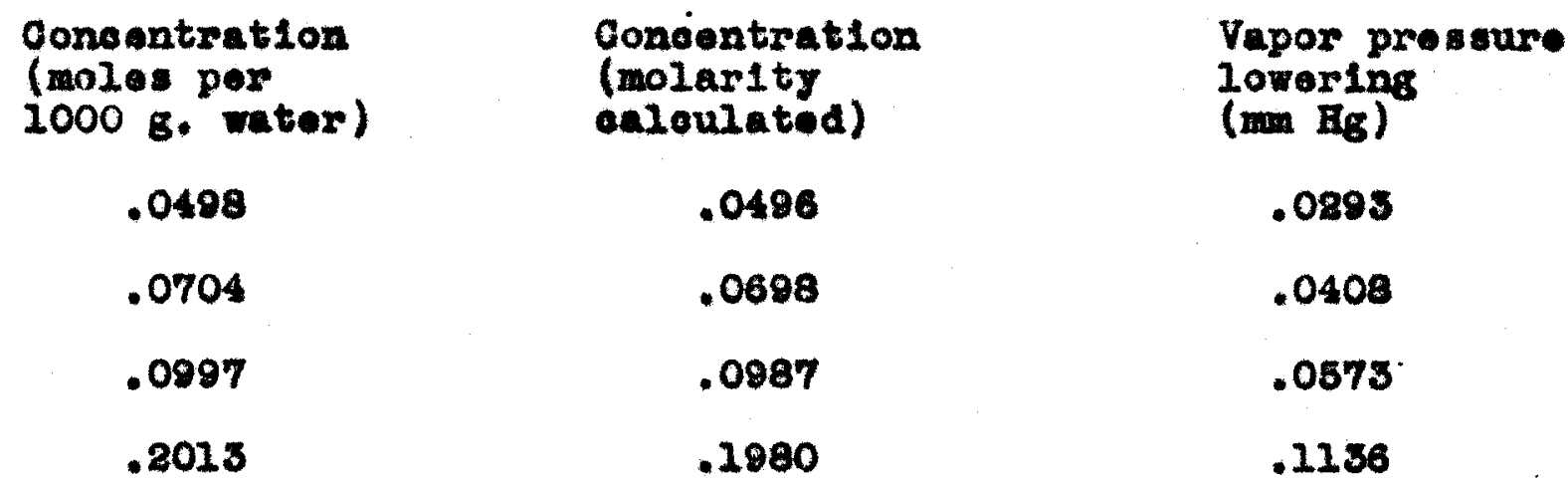

Hotes Vapor pressure of pure water at $20^{\circ} \mathrm{O} 1 \mathrm{~s} 17.535 \mathrm{~mm} \mathrm{Fg}$ 
Table VIII Donsity of Aqueous Potasalum

Chloride Solutions at $20^{\circ} \mathrm{O}$ (48)

\begin{tabular}{|c|c|}
\hline $\begin{array}{l}\text { Bongentration } \\
(\varepsilon / 1 .)\end{array}$ & $\begin{array}{c}\text { Spooiflo Chavity } \\
(\mathrm{g} / \mathrm{e} .)\end{array}$ \\
\hline 10.05 & 1.0046 \\
\hline 80.22 & 1.0110 \\
\hline 40.96 & 1.0230 \\
\hline
\end{tabular}




\section{Sample Galeulations}

Illustration 1. Computing the density of a 0.133 molar Amaranth aqueous solution from data given in Table 5 of the appendix.

Not wolght of solution is 25,8822 grams

Pyonomoter correction 1s $0.9982 / 0.9991$

$\rho$. Het welght of solution x Pyonometer correction/ Apparent rolume of solution

$=25.8822 \times 0.9982 /(25 \times 0.9991)=1.0343 \mathrm{grams} / \mathrm{co}$.

Illustration 2. Computing the equilibrium concentration of the Amaranth solution in Run I from data givon in Table 7 of appendix.

$V_{0}$ vator $5 \mathrm{cos}$

Vo std. soln. $=.5 \mathrm{ce}$.

$w_{.}=.0258$

$w_{.} .9967$

$c_{0}=\frac{\text { G. } x \text { Volume of solution in cup at start }}{\text { VoIum of solution In cup at quilibrium }}$

Volume of solution in cup at equilibrium $=\nabla_{0}$

$c_{s} x$ Volume or solution in oup at start $=1000 x$ moles of dye in oup

Honce; $O_{0}=\frac{1000 \times \text { moles of dre in oup } x \rho_{0}}{w_{0}}$

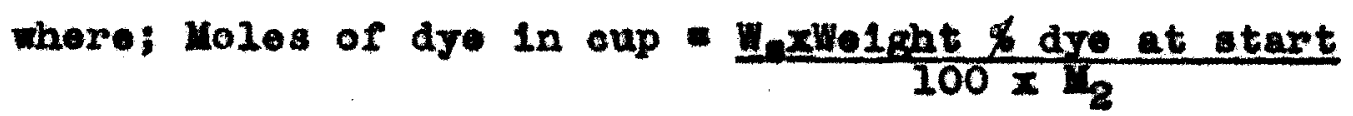

and; We1ght 8 dyo at atart $=$

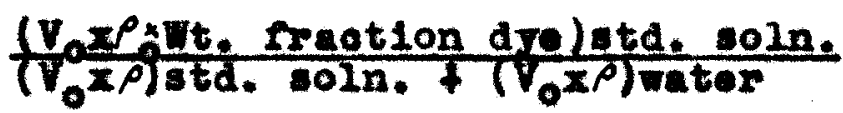

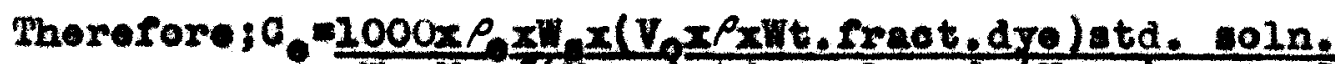
$\|_{0} x_{2} x\left[\left(v_{0}^{x \rho}\right) \frac{a t d . \operatorname{soln}}{+}+\left(v_{0} x \rho\right)\right.$ water $]$ 
Ilustration 2. Con't.

Subatituting; $P_{0}=0.8982+0.2712 c_{0}$

$u_{2}=589.604$

Pstd. soln. $=0.9982+0.8712 \times 0.233$

Wolght freotion dye in standard solution $=0.0759$

Pwater 0.9982 at $200 \mathrm{C}$

and rearrangings

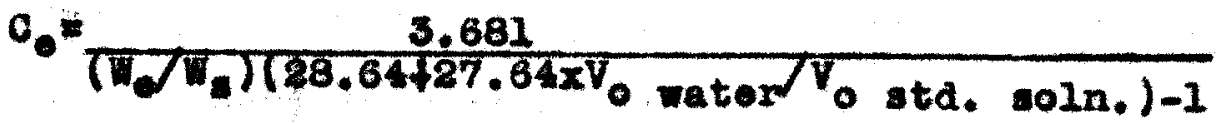

Applied to the speeifle problem;

$0 . \frac{3.681}{(0.9258 / 0.0967)(28.64+27.64 \times 5 / 0.5)-1}=0.013 \mathrm{mols} / 1$.

Illutration s. Computing the rapor presaure lowering of solutions in Run 1 using data given in Table 3 or text also equation 18 text

C $\operatorname{KaI}^{\circ} 0.017$ molax

$P_{0}-p=0.595 \times 0 /\left(1+0.186 \times C_{0}\right)=0.595 \times 0.017 /(1+0.186 \times 0.017)$

$=0.0204 \mathrm{~mm} \mathrm{Kg}$

Illuatration 4. Computing the osmotlo pressure of solutions in Run 1 uaing equation 25 of text and dita given In Table $s$ of toxt

$P_{0}-\mathrm{P}=0.0104 \min$

$P=3817.0-3068.6 \log \left(17.535-\left(p_{0}-p\right)\right)$

$=3817.0-3068.6108(17.535-0.0204)=0.9$ atmospheres 
Compounds Possessing Liquid Grystalline Phases in Solution

Compound

Formula

Tartrazine

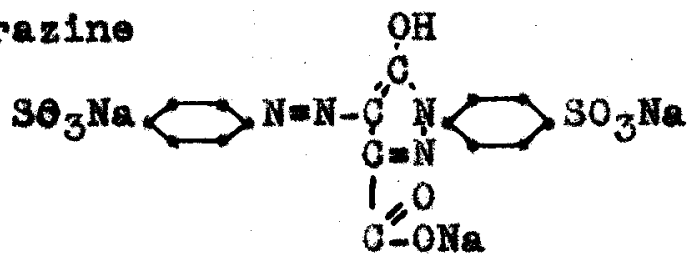

Me thylene

Blue

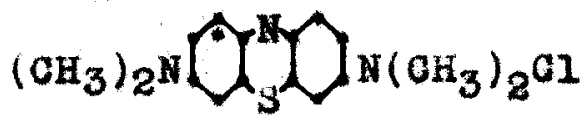

Heutral Red

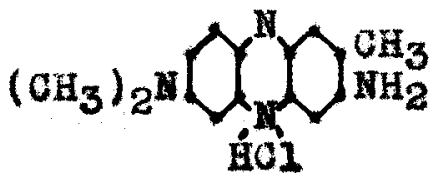

Type phase Reported by: and solvent

Nematio and (21)(22)

smootio in

water

Nemat10 in (20)(19)

water

Bril11ant Crooein

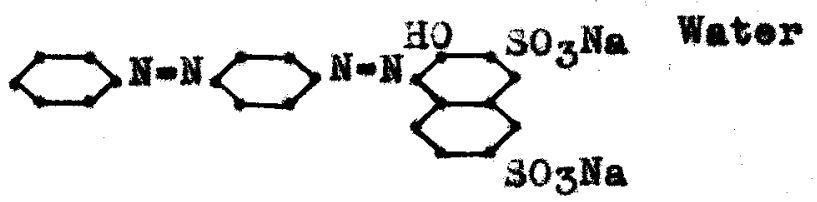

Ans 1a1-p-

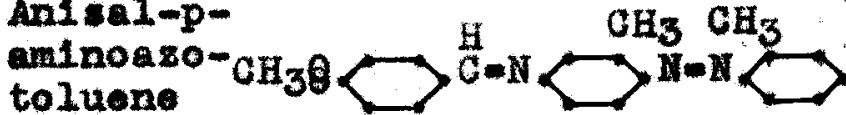

$2 t_{2} 0, \mathrm{C}_{6} \mathrm{H}_{6},(23)$

toluene Phile, $\mathrm{OACl}_{3}$. and ${ }^{0 s_{2}}$

10-bromophenanthrens -6sulphonic aold

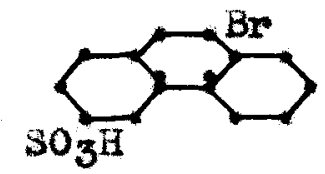

Nematic more(51)(53) hydrated

than Smeotic

$(25)(26)$

10-ohlorophenanthreno-6aulphonio ac1d

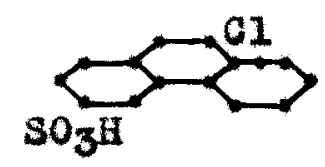

Water

Potassium Methyl

Orange

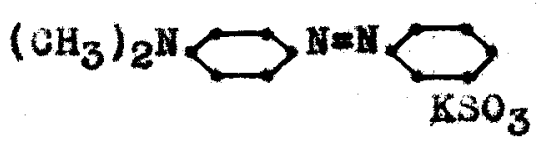

n

3alvarsan

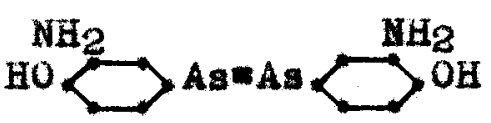


Compound

Anisal $\alpha-$ beneal -

aso- $\alpha$ -

naphthyl-

amine

Sodium

benzosto

Sodium

m-bromo-

benzoate

Methyl-

ene

Green

cyanine

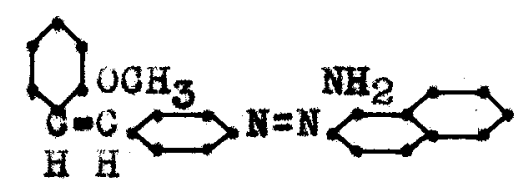

Pormula

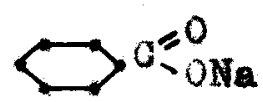

$\left(\mathrm{CH}_{3}\right)_{2} \mathrm{CHCH}_{2} \mathrm{CH}_{2} \mathrm{~N}_{-\mathrm{NH}=} \sum \mathrm{N}_{\mathrm{CH}_{2} \mathrm{OH}_{2} \mathrm{CH}\left(\mathrm{CH}_{3}\right)_{2}}$

Gallo-

oyanine

$\left(\mathrm{CH}_{3}\right)_{2} \mathrm{~N}^{\mathrm{NO}} \mathrm{CH}^{\mathrm{N}\left(\mathrm{CH}_{3}\right)_{2} \mathrm{Cl}}$

at $110^{\circ} \mathrm{C}$

pure

Water

n

$\longleftrightarrow 0=0 \mathrm{ONa}$

Aloohol

$n$

Typo phase Reported by: and solvent

Water. Also

olearing pt.

(53)

w

cyanine

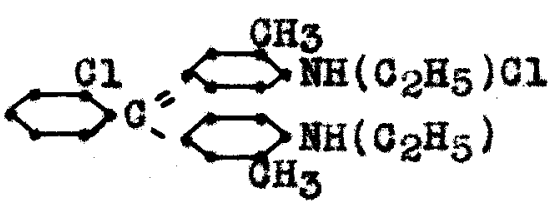

n

Blue

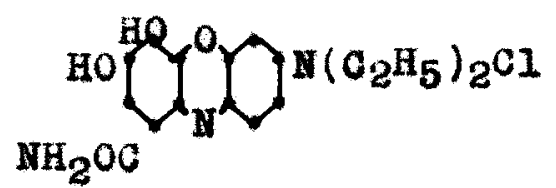

Past Bluo

$$
\mathrm{C}_{20} \mathrm{H}_{15}\left(3_{3} \mathrm{Na}\right)\left(\mathrm{O}_{6} \mathrm{H}_{5}\right) 3_{3} \mathrm{~N}_{3} \quad \text { " }
$$

(sulphonatod

AnIline Blue) 
Dampouna

Pormula

Iow Mothy 1one Blve

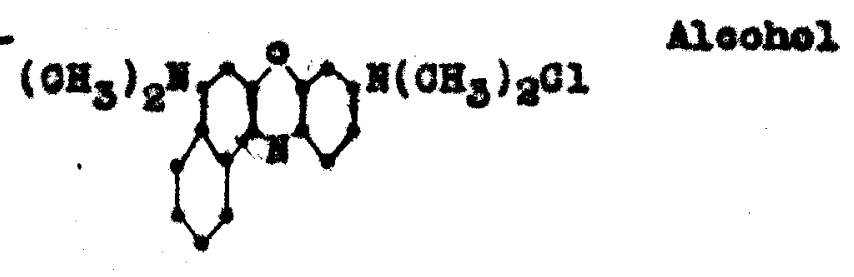

Type phase Reported bys and solvent

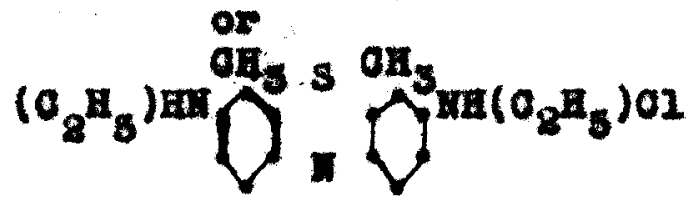

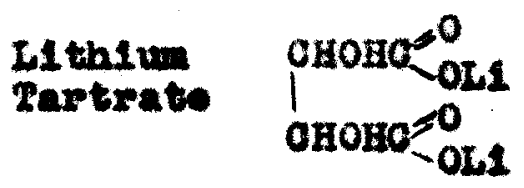

Commerelal orgoc=0

Loestrin

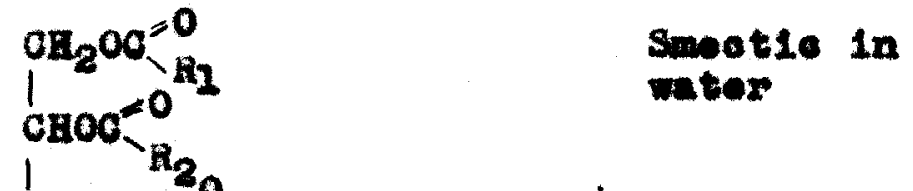

Water

(58)

(11)

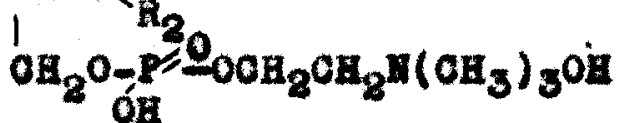

( $R_{1} 00$ and $R_{g} 00$ pepreaent aegl groups of the hither ratty aelde)

Potareivm

OLeate

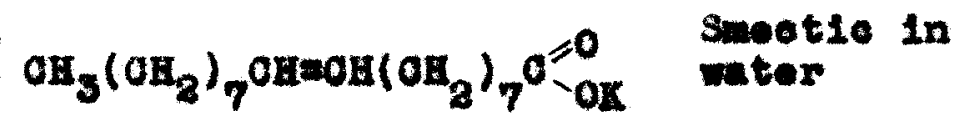

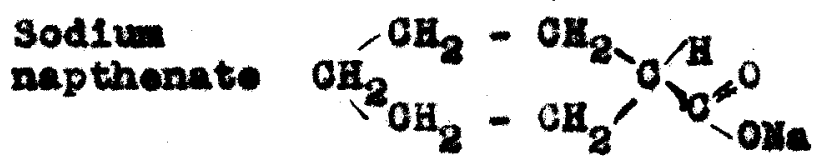

.

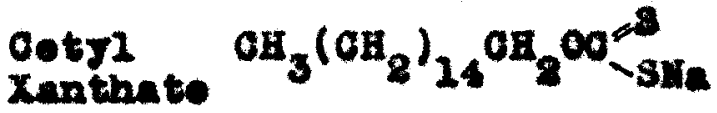

n

Sodivm

Palmitato

$$
\mathrm{CH}_{3}\left(O \mathrm{~B}_{2}\right)_{24} \mathrm{O}=0
$$

Sodsum $\quad \mathrm{OH}_{3}\left(\mathrm{CH}_{2}\right)_{20} 0=0$

*

Sodium $\mathrm{OH}_{3}\left(\mathrm{OH}_{8}\right)_{7} \mathrm{OHEOH}\left(\mathrm{OH}_{2}\right)_{7} \mathrm{C}=\mathrm{OH}$ 
Compound

Formala

Dodeojl sulphonio aold

Sodium

Stearate

Sodium

Myristate

II thium

Palmitate

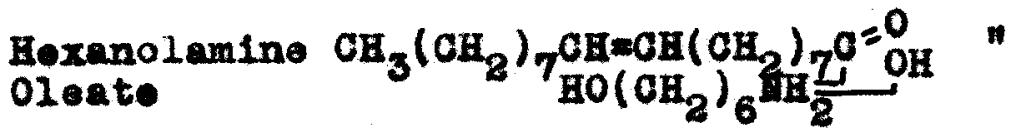

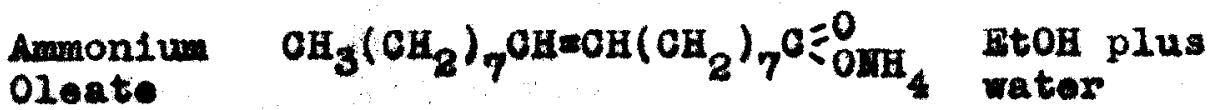

H,W'-diothyl

psoudo1so-

c yanino

ohloride

or

D1ethyl- $\psi$ -

ojenino

obloride

PInaoyanol

$$
\mathrm{CH}_{3}\left(\mathrm{OH}_{2}\right)_{21} \mathrm{SO}_{3} \mathrm{H}
$$$$
\mathrm{CH}_{3}\left(\mathrm{OH}_{2}\right)_{16} \mathrm{C}^{\mathrm{O}}=\mathrm{OHa}
$$$$
\mathrm{CH}_{3}\left(\mathrm{CH}_{2}\right)_{12} \mathrm{C}_{-\mathrm{OHa}}=\mathrm{O}
$$$$
\mathrm{CH}_{3}\left(\mathrm{OH}_{2}\right)_{14} 0=0
$$

Water
Type Phase Reported by? and solvent

Smeotio in

wator

n

n

u

Wator

$(56)(57)(58)$

$(59)(60)(61)$

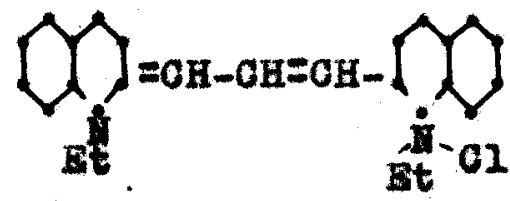

(60) 
Compounds Ylelding Sols which Rosemble Ilquid Cryatalline Phases (*)

Compound

Bentoni to - lej

Vanadiun pentoxide

Tobacoo mosale

Protein cryatal.

Iron oxide

Silver

oyanato

Benzopurpurin $4 B$
Formala

$$
\begin{gathered}
\text { Hydrated Sodium } \\
\text { Aluminum Silloate } \\
\nabla_{2} \mathrm{O}_{5}
\end{gathered}
$$

Inderinito

Inderint to

$\mathrm{Po}(\mathrm{OH})_{3}$

Agoro

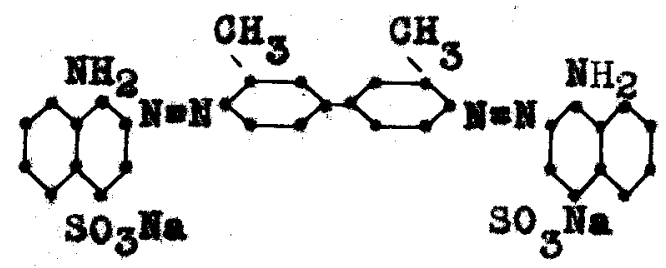

Benzobrom Probably:

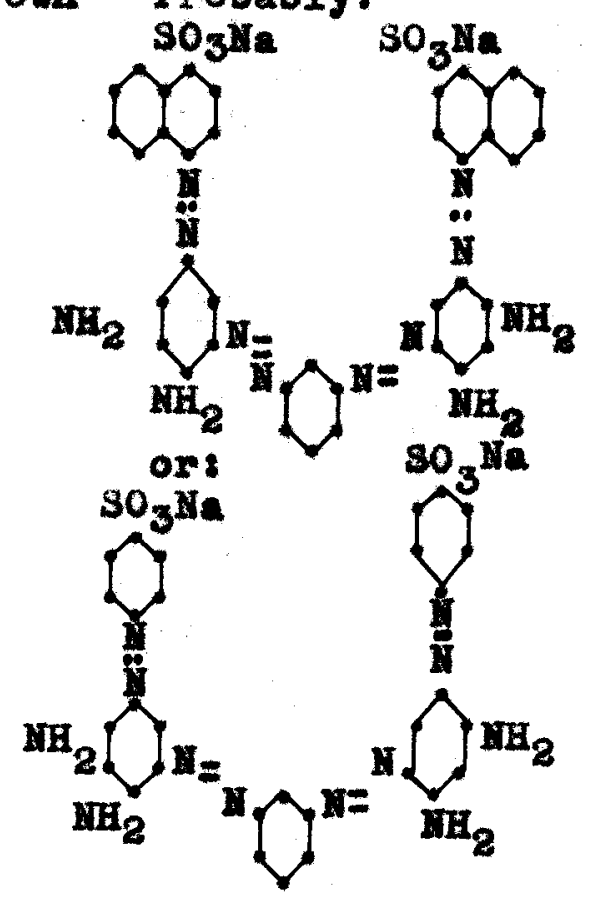

Disperalng Reported by: modium

Water

$(8)(62)$

n

$(9)(62)(63)$

(64)

(8)

(8)

(8)(64)

(8) (64)

(62)(63)(64)

$(65)(66)(67)$

(68) $(69)$

(62) 
Compound Pormula

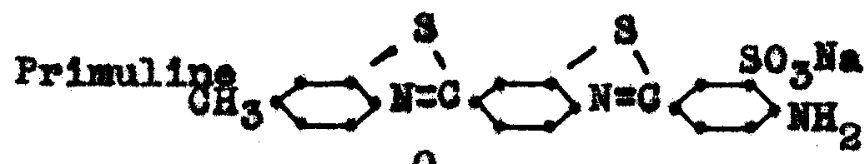

Alisarino

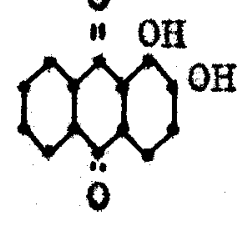

Sodium ellarino sulphonate

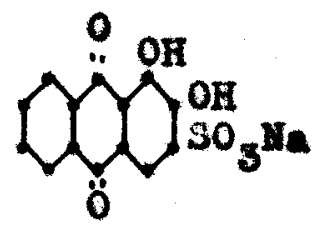

ต

Anthracono<smiles>C1CC2CC3CCCC4CC5CCCCC5C4CCC3CC2C1</smiles>

a

Coravin

Orange

Hot arallable
D1spersing Reported byt modiun

Wator

$n$

$\mathrm{SO}_{3} \mathrm{Ha} \mathrm{SO}_{3} \mathrm{Ha}$ Water

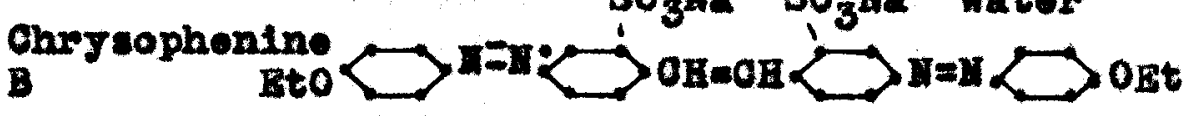
${ }^{\mathrm{HO}} \mathrm{CO}_{2} \mathrm{Ha}$

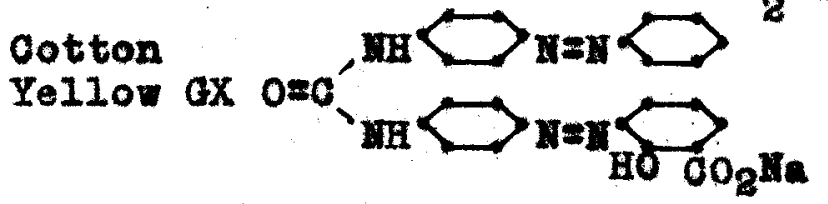

Water

$(63)(69)$

Dissolved

In BtOH:

then poured

into rator

(62)(70)

Blue 8 BL

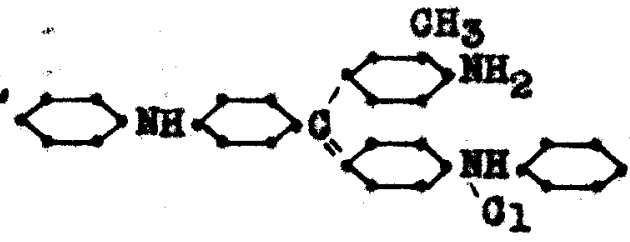

Hot arailable

(n

(70)

Sudan Blue

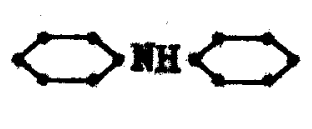

Water

(71)

Motan11

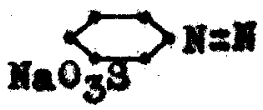

A group of 160 dyes

Inrostigated (n) using flow tookni que 
Compound

A group of 450

djos
Pormula

rese
Dispersing Reported bJ: medium

Invest1gated (71)

using photo-

anisotrop10

toobnique

Wote: (*) Those compounds in most cases yleld tranoparent coherent sol phases whlch are olalmed to resemblo liquid orystelline phases in solution booause they oxhibit atroaming double refraction and are oomposed of colloldel mieollos consisting of rod haped partiolos with parallol orientation whloh at higher conoontrations opontanoously collect into orlented group: (tactolds) the physloal nature of whloh closeis resembles that of the swara in liquid orgstalline solution. The sol phase is different in 1 ts reaction to externaliy appliod forose such as those existing on an anlsotrop10 surface. Thls test may oren be completely negative. The sols are also distinguiahod by the low tmae solubility of the solute and mothod of preparation. The l1quid oryatalline phase in solution is developed as the result of simple solution of a compound in a solvent, mereas the sol formation requires dispersion toohnique with partioular attenti on gi ron to dispersire temperature and $t$ imo and solute conoentration as well as ut111sation of intermodiate solrents.

It 1s apparent that the 801 phase 1s motastable beoause it changes with time porhaps through the unsatiafied fores of oryatallization. The equilibrium diagram for tho majority of systems probably resembles Flgure 12 exoept that 
the regions of coexistent phases and mosophase are non-oxistent, and the common linit of solubility shifts to a mach lower range of conoentration being about $0.35 \%$ by welght in the esee of aqueous Bensopurpurin 4 at room temperature. The phases existing in the rounining shaded axea of the diagram then beoome MIlquid oryetalline like sol phase (netestable)" or "solid (atable)" and "isotropie solution".

There is an altermative explanation for tho equilibrlum diagran for some of the subjeot materiala if one coniders their solution as bolng supereaturated rather than o01101dal. In this sese the common lind of volubility in Figure 18 would ahift as before but the regions of coexieting phases and mesophase would remain. The reglons bounded by the common limit of solubility and the outer boundary of the cooxistent phases region would represent "supersaturated solution" (motastable). The coexistent phases region would represent "eupersaturated solution" (motastable) and "mosophase" (metastable). "These regions and the metastable "mesophese" region would obnage with time erentualiy bolng transformed to the stable solid and stable 1sotrople saturated solution. The present theory probably applies to both the auperseturated solution type and the sol type system. Howerer, In the latter ease, $1 t$ would be noeessary to first dotermine the electrienl character of the rod ahaped partioles. 


\section{Bibliography}

Periodieals

\section{Coseorration}

Bungenberg de Jong, $B$, G., Morlented Conenrrates and Theis Boaring Upon the Bormation of Collold Crystala," Proc. Aoad. Sel. Amsterdam, 38, 426-34 (1935)

Bungenberg do Jong, H. G. and Bank, O., "Boharlor of Mlcroseoplo Bod1es Consisting of Blocollold Systems Surponded in Aquoous Modium, "Proo. Aoed. Sol., Ansterdam, 42, 83-8 (1939)

Bungenberg do Jong, H. O. and Linde, P. V. D., "Concervate Sols and Thoir Relation to the Theory of Lyophilie Collo1dal Stability," Proo. load. So1. Noutordam, $38,419-26$ (1035)

Bungenberg de Jong, H, G., Saubort, G. G. P, and Booy, H.L., Influenoe of Orgenle loneleotrolytes on Olexte and Phosphat1de Conoervates," Protophnama, 29, 481-97 (1038)

Bungonberg de Jong, H. O.; Saubert, G. G. P., and Booy, H.L., "Influence of Organio Honeleetrol jtes on 0leste and Phosphat1de Coacervates," Protoplasma, 30, 1-38 (1938)

Bungenberg do Jong, H. G. and Winkler, K. C., "Dlaintegration in Crystalloldal Heutral Sait Solution Analogous to Complex Concervation of Blocolloldal Solutions," $\mathrm{Z}$. anorg. Allgem. ohem., 232, 119-32 (1937)

Dobry, Me. A., "Coacerration," J. Ch1m. Phys., 35, 387-94 (1938)

Dobry, Huo. A." "Concervation," Rer, can. b101., 1,353-65 (1948)

Kruyt, H. R., "Tho Stablilty of Collo1dal Solutions," Bull. Soc. Onim., (5), 4, 1925-41 (1937)

Kruyt, H. R, and Bungenberg de Jong, H. O.. "latension of the Theory of Complex Coacervation to Ionic Disperse Systoms," Proc. Aoad. Sol., Amatordam, 38, 714-21(1935) 
P1renne, H., "liquld Proolpitations. Application of Coucorration Theory to Blectrolytes", Rev, unirerselle mines, 13, $227-8$ (2937)

Sehoors, J., "Complex Coaeorvationg", Rev, universolle mines, 13, 219-27 (1937)

TJadon, R. S., Moddorman and Holloman, L. W. J., "Coecervation" Heture, 129, 654 (1932)

\section{Llquid Crystalline Molts}

Bogojarlonaki, A, and winogradow, M., "On the Relation of Molting Polnt and Clarifleation Polnt Curves of Ilquid Crystel and Mixtures of the same", Ohem, Lab. UnIv. Dovpet, Z, physik. Ohem., 60, 432

Bose, B.. "For and against the prulsion Thoory of Grytalline Liquids", Toah. Hoohsohule, Dansig Langrubr. Physik. 2. $8,513-18$

Bose, B., "moory of Anlsotroplo Liquids II", Danzig., Phyaik. z. $10,230-44$ (2909)

Bose, I., "On the Physioal iroperties of Bmalalons, in Part1oular Conoerning Tholr Relations to Crystalline Fluids". Physik. Ze1tsohr., 8, 347 (1907)

Bradrleld, A. B, and Jones, B., "Two Apparent Casos of Liquid Orystal Format1 on", J. Ohem. Soc. 1929, 2660-1

Ohatelaln, P., The Orlentation of Llquid Orystale by Stroked Surfaces", Compt. rond. 214, 38-4 (1942)

Conrat, F., "Ohange of Donsity of Anleeldasine at the Olearing Temperature", Phyalk. Z., 10, 202-6

Hort, L, and Hartel, H. V., Mno Dipole Momontume and the indsotropy of Liquids" "Fhysik, Z. 28, 786-90 (1827)

Poex, G.. Oryatallisetion of Mesomorphlo Substances in the Hegnotic Field obtaining a Solld with Orlentated Holosules", Oompt. rond. 187, 822-3 (1828)

Friedel, Q., "The Mesomorphie States of Matter", Ann. phyalk., 18, $273-474(1982)$

Gaubert, P., "The Ifquid Crystals of Anisal-p-amino asotoluono" Compt. rond., 176, 907-9 (1923) 
Gaubert, P. "The Planes of Grandjoan", Compt. rond, 177, 698-

Grandjean, F., "Application of the Theory of Magnotian to Anisotrop10 Ilqulds", Compt. rend 164, 880-3 (1917)

Kast, W., "Cond1tions for Appearnnoe of an inisotrople Liquid Phase". Maturwissonsoharton, 25, 234-5 (1937)

Lohman, 0., "Rxtension of the Sphere of Bxistonoe of Fuid Crystels by Admixture", Ann. Pnys1k., 4 21, 181-92 Larlarubo

Lyons, $O$, $Q$, and RIdeal, E. I., Mphaso Diagrams for Unimoleoular P1lms". Proc. Gambridge PhIl. Soc. 26, 418-20 (1930)

Orasteln, L. S., Kast, W. and Bouma, P. J., Nhe LIquid Crystal Oharacter of Dipole Fiulds at the Melting Polnt". Proo. Aead. So1. Amstordam, 35, 1209-12 (1932)

Oscen, C. W., "Contribution to tho Theory of Anlsotropio Liquids". Arkiv, Hat. Astran-Fyu1k 18, \#8, 23pp (1983)

Robbereant, J., "Plezomotrle Researoh V. Anlsotrople LIquids Under Pressure", Bull, s00. Ghim.-Belg. 47, 597-638 (1938)

Vo1gt, W., HLlquid Cryatals and Anlnotrop10 Llquida (Supplimont I", Cottingon. Phys1k. z. 17, 305-7 (1916)

Vorlander, D.. "Colloldal Solutions of Dyes and of Colophony in Liquid Ory stals", Z, physik, Chem., 85, 701-5

Vorlander, D., "Inrestigation of the Holooular Forre by Koans of Crjstalline Liquids", 2, phja1k, Ghom. 105, 211$54(1923)$

Vorlander, D," "Iow Orystalline Fluids", Z. physik, Ohom., 57, $356-64(1907)$

Vorlandor, D., "Optioal Volds, Orystaline Llquids and Varlous Kinds of Orystalline Llquids", Phyalk. 2., 31, 42835 (1930)

Vorlender, D., "Polymorphlam or Crystalline Liquids", Ber., 70, $1202-12(1937)$

Vorlander, D., "Pol yoorphlam of Liquids", Chem. Inst. Univ. Halio a. S. Bor., 40, 4587-37 
Vorlender, D., and Plechor, J, The Uniexlal Direation of Crystali1ne Liquids", Bar., 63, 2506-10 (1930)

Yorlander, D. and Gahron, A., Formation of Cryatali1ne Liquids by Mixing Substanses", Chem. Inst. OnIv. Haile a. S, Ber., 40, 1966-69

Wojgand, C. and Gabler, R., The Rffect of Holecular structure on the Appearanee of Ilquid Crystals, Haturwissenscharton, $27,28-9(1930)$

Wejgand, a. and Oabler. R., NEew aroup of Orgatalline-11quid subatenee, the Homologous p. P-diphenylpyridaxine", J. prakt Ohem, $215,221-6$ (19se)

Woygand, O. and Gabler. R. "Oocurance of more than Two Polyworphie, Orystiline-11quid Phases in Aromethine Compounds", J. prakt. Ghem. 151, 215-20 (1938)

Wergand, G. and Gabler, A., Motardation of Arrangemont Botwen Ordinary and orsatalilno Ilquids an wil as

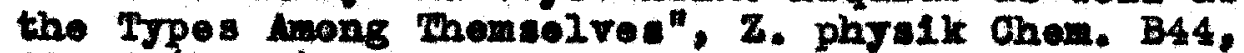
$69-74(1839)$

Weggand, C. and Gabler, R., The Thermal Peralstenee of Grjatalline Llquid Phases", Ber., 71, 2399-2405 (1938)

W11Lers, F. A., VIseosity inomalles of Mmilaion in the Oondition of Turbuient Plow", Danis Physik. z., 10, $244-8$

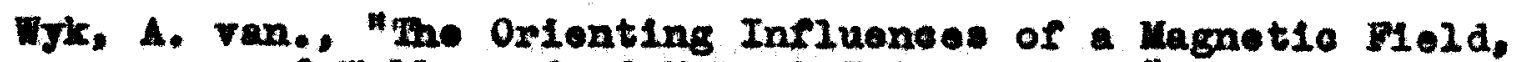
of Walla and of Mutual Intarestiona", Ann. Phyelk 5. 879-933 (1989)

Zocher. H, The Aetion of Magnet10 Mloetrio and Heahanical Fores upon Lesophnees", Maja1k, Z, 28,790-6(1827)

\section{Llould Crrateline solutions}

Cornish, R. C. V., "Donalty Meamurementa of Soep Solutions". 2. physix. Ohon, $76,810-11$

Conidx, B. and MeBain, J. W., "Cryoneopio Bvidonee for M10e110 Aasoolation in Aquoous Bolutions of Nonionis Detergents".J. An. Chem. Sos, 69, 334-336 (1847)

Lehmann. 0." Ionio Mgration In Iquid Crytal of Hydrated Amoniwn 0leate". Ann. Physk. 57, 244-56 (1918) 
Sandqvist, H., Mabular Reviow of the Literature on Phonanthrone Derivatives for the years 1908-1912 incluIre". Arb. Vtgirne Lod. Understod of W1inom Elemans Unireraltetefond, Oppania No. 14. 106pp

Sandqvist, H. and Hagelin, A., Mono and Dlohloro Phonanthrone", Ber. 51, 1515-26 (1918)

Somorfeldt. F. The Investigation of Inquid Orjatals in Oonverging Polexized Light". Physik. Z. 9, 234

Vold, H. J.: Hiquid Orystaline, Waxy and Orgstalline Phases in BInary Mixtures of Fure Anhydrous Soaps".J. Im. Ohom. Soe. 63, 160-8 (1944)

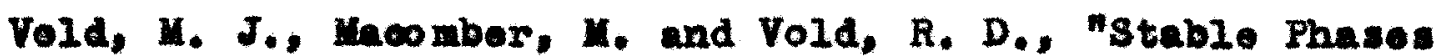
Oecuring Between True Orystalline and True Ilquid for Single Pure Anhydrous Boapa", J. An. Ghom. Soo.. 65. $168-75(1941)$

Vold, R. D.. "Anhydrous Sodium Soapa, Heats of Iranaltion and Giasalfiention of the Phase,"J. Am. Chem. 300.63. 8915-84 (1941)

Vold, R. D., "Soap Phasea", Soap, 16, 31-4,11, 75-4 (1940)

Vold, R, D., L1ggett, O. W. and MeBain, J. W. "gystems of Sodium Palmitate In Organie Llquids, J. Phyolo. Ghom, 44, 2058-72 (2940)

Vold, R. D. and Vold, I, J., Mtherwal Transition of the Alkall Palmitates", J. Phys. Chem, 49, 52-48 (1945)

Wallerent. P. "On the Fuid Crystal of Amonsium Oleate". rond. 143, $694-95(1807)$

\section{Itwe of Dre Solutions}

Bajl1as, "The Properties of Colloldal Systems. The Oamot10 Preasure of Fleotrolytieal Dissoelated Collo1ds". Proo. Roy. Soc. (London), B84, 289-54 (1911)

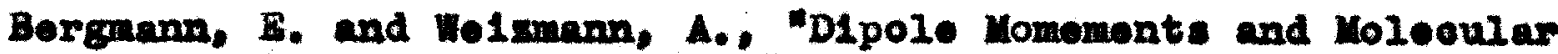
Strueture XVII. The DIpole Nomomonts of Aro Dyes and some Simllar Substanses", Mrans. Raraday. Soe., 32. $1318-26(1936)$

B11tz. W. "Omot1e Fresaure of Gollo1de. III Further Contributlons to the Dialjais and Oamosis of Solutions of Dyes", Z. phya1k. Ohom., 77, 91-116 (1911) 
B11tz, W. and Vegesack, A, "0nmot1e Pressure of Collo1da, II 0emot1e Pressure of Some Dye Solutions", Z. physik. Chom. 73,481-518 (1910)

BLd, C. L. Hodern Theory and Praet1ee of Wool Dring III The Iature of Solution:" Text1le Recorder \#707, 34, 36, $39(1948)$

Brejer, B., "The Breet of Subutituents on the Ohemieal Physloo-ohomieal and Blologloal Bohavior of Chomion Compounds. 1 theory of the Relation between Chomioal Constitution and Blologieal Aotion, Bloohem. Z.. 301. $65-03$ (1939)

Beintsmeror, H. and Sohnil. A., "Determination of the Welght of Organie Dyo Ions by Dialye1" " Z. anorg. allgom. Chom. 225, 213-16 (1935)

Brodie, N. and Ademe, R.. Moptleally let1ve Dyes II Lbsorpt10n",J. An. Ghom, Soe., 46, 2058-43 (1924)

Donnan, F. A. and Furr1s, 4. B., Nosmot16 Prosare and Conduet1rity of Aqueous Solutions of Congo Red and Rereralble Rquilibria",J. Chen. Soe. (London), 99, $1554-77(1911)$

Durfee, W. C.. "The Irwerieal Solubility of Dyes", Proc. An. Assoo. Text11e Ohem. Ooloriet, (1931) 103-4; Am. Djestufe Reporter, 20, 185-6 (1981)

Carnor, N." "Oap1llary Phonomena Bulb1ted by Dyo Solution: and Sole". J. Soo. Dyers and Colouriats, 49, 346-55 (1833)

Chosh. J. O. and Datt. S. O.. "Variation of the Surfese Tension of Aqueous Solutions of Certain Dyesturf with tine". J. Indien Ohom, Soe.. 6, 803-10 (1829)

Chowh. J. O. and Jath, M. C., "Variation of the Surface Tonsion of Aqueous Solutions of Certain Complox Orgenie Substanse wth ime". J. Phys. Chom. 36, 1916-87 (2938)

Cotse, I., Reoullar Djes Obtalned Instead of Pseudoejanines," Angew. Chem. 49, 563-4 (1936)

Ener. F. H., "Pseudoejanine Condonsation", J. Chem, Soo., 1828, $206-16$ 
Hammarston, B., and Hammerston, H, "The Oamot10 Pressure of Sevoral Bloetroljtes of Higher Holeoular Welght", Arkiv. Kom1. Minoral Geol., (27), 8, 16pp. (1923)

Hartiey, and Robinson, $0 .$, "The Diffusion of Collo1dal Hlectroljtes and othor Charged Collolds", Proc. Roy. Soc. (London), A 134, 20-35 (1931)

Heyl, G.. "Oolloldal Properties of Dyes", Color Trade. J.. $13,190-3(1923) ; 14,47-9,149-51 ; 15,4-6$ (1924)

Hollborn, K., "Saturated Solutions of Dyestuffs", Pharm, Ztg., 72. 497 (1927)

Holmos, W. C., "Colloldal Phonomona in Dye Solutions", J. Am. Ohom. Soo.. 49, 790-1 (1927)

Holmos, W. C.. "Staln Solublifies I Data In Literature", stain Teah.. 2, 44-9 (1927)

Holmos, W. O. and Poteraon, A. R., "Transmisalion Spectre or Dyes in Solld State", J. Phya. Cham., 36, 1848-54 (19 32)

Jablonsk1, C. F., "Roport on (the determination of) Doloring liattor: In Pood; (Quantitativo Soparation of Amaranth and Tartragino $"$ ". J. Assoc. Offleial Agr. Ohem., 11, 434-8 (1928)

Jablonsk1, O. P., "Roport on (the analyals of) Coloring Natters (used) in Poods", J. Assoo. Offloial Agr. Chow., 13, 412-6 (1930)

Jablonak1, $0 . F_{.}$" "Roport on (the determination of) Coloring llatters in Pood". J. Assoo, Orflolal Agr. Chom.. 15. 368-9 (1938)

Jolley, B. B., "Speetral Absorption and Fluoreseence of Dyes in the Noleowiar state", Hature, 138, 1009-10 (1936)

Jorpes, E. and Hellgron, R, G., "The Oamotie Pressure of some Mloetroljtes or High Molocular Welght", Blooben, $z$. 145, 57-62 (1924)

Inoeht, B. and Bately, J. P., Mondition of Somo Dyestures in Aqueous Solution", 7 th Int. Cong. Appl. Ohem.. London 1910, J. Chem. Ind., 28, 697

Laver, W. and Millor, S., "The Strueture of Hydroxyase Compounds", J. Am. Chem. Soc.. 57, 520-25 (1935) 
Lehner, S, and Smith, J. B., "Dyeing of Cotton: Partiolo S180 and Subatantivity I", J. An. Chem. Sool, 57. 497$504(1935)$

Lohner, 3. and Smith, J. R., "Dyelng Cotton. Substantat1re Dyos and Salt Sonaltirity". Ind. ing, Ghem. 27, 20-5 (i035)

May, O. B. and Hunt, H., "Some Aso Dyes Soluble in Non Aqueous Solvents". Ind, and Engs. Okem., 20, 384-88 (1928)

MoBain, J. W. and LIu, T. H, "Dirrusion of Eleotrolytes, Mon Blectroljte and Colloldal Bleotroljtes", J. Am. Chon, Soc. 53, 58-74 (1931)

Horgan, 0. T, and KIng, H. J. S., Mes1dual Affinity and Coordination. IX Cobaltamine Salts of the Hitro Drea" J. Ohom. Soe. 121, 1723-9 (1882)

Horton, T. H. "DJelng of Celluiose w1th direot Dye sturfa. Importance of the 0olloldal Constituents of the Dye Solution and of the Fine stmeture of the Fibre". Trans. Paraday. 300..31, 262-84 (1835)

Rabinowitah, R. and Epate1n, L. P.. "Polymerizetion of Dyeature in solution. Thionine and Methylen Blue", J. An. Chem. \$oo..63,69 (1941)

Robinson, O." "Difrusion Coefriolents of Dye Solutions and The1r Interpenetration". Proc. Roy. Soo. (London) $4148,681-95(1935)$

Rob1nson, O.. "Dyesturfs as Collolds". J. Soo. Dyers and Colourists, 50, 161-5 (1934)

Robinson, O. "Heture of tho Aqueous Solutt ons of Dyosturfs" Trins. Faraday 300., 31, 245-61 (1935)

Sahe1bes O.. NHechanian of Sensitixation of Photochemieal Reactions Bsposially the Assimilation Roation bJ Dyes", Haturwissensohafton, 25, 795 (1937)

Sheinker, 1. 3." "Study of the Degree of Disporsion of Dyea by the Diffusion Nethod".J. Phys. Ohem. (USSA), 4, $860-4,865-70(1933)$

Shopperd, S. E. and Goddes, 4. L., "arfeot of Solvents Opon the Absorption Speotra of Dyos. IV Water as Solvent: A Common Pattern". J. An. Chem. Boc., 66, 1995-2010 (1944) 
Standing, H. A., "Dyoing of Cellulose with Diroot Dyes", Trans. Paraday Soa., 41, 410-34 (1945)

Tanaka, R., "Collo1d Chemleal Studies on Dyeaturs Sols I Sol Pormation of the Congo Aold by Washing Poplization, Kollo1d, Z., 53, 200-5 (1930)

Valke, B. I., Messurements of the Difrusion of Dyesturer, Trana. Paraday. Soc.. 31, 230-245 (1935)

Valko, B. I., Partiole S1ze in the Vet Dyelng of Oellulose", J. Am. Chem. Soe.. 63, 1433-1437 (1941)

VIokerstaff, T. V. and Lomin, D. R., "Aggregation or Dyes in Aquoous Solutions", Hature 157, 373 (1946)

Woltsion, W. and Gotse, X., "Substantative Dyos (salt colors) and their Behavior Towerd V1s0o se and Ouprammonium Rayon II Dyeing of Rayon". Seldo, 32, 401-13 (1987), Ohaw. Zentr. 1928 I, 975-6

Zsigmondy. R.. "State of DIVIsion of Dyes of High Moleoular Welght in Aqueous Solution", Z, physik. Chen,. 111. $211-33(1924)$

\section{Option Aotivity in Colloldal Solutions}

Ohatialn, P., "Tho Seattoring of IIght by LIquid Crystals". coupt. rend., 218, 652-4 (1944)

Fruendlioh, H., "Colloldal Struetures in Blology", J. Phys. Chom. 41, 1151-61 (1937)

Fruendliah, H. "Double refraction of Vanadium Pentoxide Sols", Z. Blektro, Ohem. 22, 27-33 (1916)

Fruendlioh, H, and Diesselhorst, H., "Double Refrection of Vanadium Pentoxide Sols". Physik. Z. 16, 19-85 (1915)

Oster, G., Doty, P. M, and ZLm, B. H., "Light Scattering Studies of Tobacco Virus", J. Am. Chem. Soc. 69, 1293-97 (1947)

Theory of $0010 x$

Bury, C. R., "Awrochromes and Resonance", J. Am. Chem. Soe. 57, 2115-2118 (1935) 


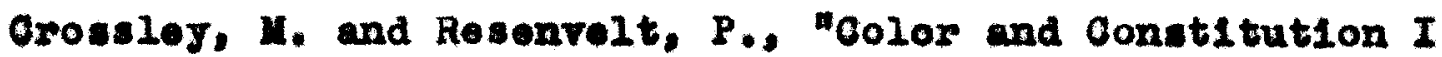
Brfeet of Inomorian on the Color of Certaln Axo Dyes", Ind. Fng. Ohem. 16, 271-3 (1924)

Raman, C. V. and Bagavantegn, S., "Tho Relation Betwoen Color and Moleoular Strue ture in Organle Compound", Indian J. Phytolos, 4, Pt. 1, 57-78 (1929)

Reynolds, W. B., "A Slmpilfled Disoussion of Color and Conatitution of Azo Dyes", Am. Dyesturf Reporter, 32, $455-6,465-7(1943)$

Thoory of Ionlzed Solutes and Hature of Solutions

Amold, O. and W1Illams, J. W., "The Reslatanoe and Capacity Beharlors of Strong Blectrolytes in Dilute Aqueous Solutiona. I Method for the Simultaneous Observation of Conductanee and Dielectrie Constant at High Rad1o Frequene1es". J. Am. Chem. Soe., 58, 2613-24 (1936)

Baborovaky, J. and Vallsek, J., "The Absolute Hydration of $\mathrm{H}$, L1, Ha, $K, 01$, and Br Ions in Tholr Normal Solutions", Ohem. Liaty., 21, 227-31 (1927)

Birline, T. and Pajans, $X .$, "Hature of the Covalent Binding", J. Chem. Phys., 10, 691-2 (1942)

Bjorrum, H.. "Therrodynales of Aotivity Coefficlents and oamotie Coefrieiente", Z. physik. Chem., 104, 40632 (1923)

Bonino, a. B.. "A Theory of Conoentrated Solutions of Strong Bleotrolytes I Theoretioal Gonsiderations", Mom. aco1d. Italle, 4, 415-44 (1933)

Bonino, G. B. and Controla, G., " $A$ Theory of Conoentratod Solution: of Strong Fleetrolytes. Posalbility of 1ts Applieation to the Caloulation of omotio Cooff1clents", Ltt1. cooad. Linoel., 18, 145-9 (1933)

Bonino, G. B. and Rolla, M., "III Caloulation of the Loworing of the Vapor Pressure of the Solvent", Ibid, 165-70

Bonlno, G. B. and Valglio, V., "Ionie Radius and Omotic Aetivity", Gasx. Ohim. 1tal. 59, 49-56 (1929)

Boxm, M., "Volumes and Heats of Hydration of Ions", Z, Physik I. 45-8 (1980) 
Borm, X, and Heisonberg, W., "Inrluence of Deformability of Ions on Optioal and Chemiorl Constants". Z. Physik,. 23, 388-410 (1924)

Bottaher, O. J. F., "Computation of the Radius and the Polar1zability of a llumber of Ions", (Rotterdan) Rec. trev. chim.. 65, 19-38 (1946) in Bingliah

Bottoher, O. J. F., "A Dirforential Method for the Caloulation of the Mean Radius of Partieles". (Rotterdam) Hoo, trav, Ohim., 65, 14-18 (1946) in Inglish

Bottoher, O. J. F., "The Molecular Refraction of Aqueous Solutions of meotrolytes", Rotterdam Rec. trav. ohim., $65,39-49$ in English

Bronstead and La Mor, "The Metivity Coefrlelonts of Ions in Vory Dilute Solutions", J, Am. Chom, Soe., 46, 555$74(1824)$

Cavallaro, L., "Oryoscople Investigations IV Galoulation or the Cryosoople Lowering of Aqueous Solutions of Alkaline Ohiorates and Alkaline Earth Ohlorates", Cazs Ohom. Itel, 71, 269-88 (1941)

DeBye, P. and Pauling, "Interionio Attraction Theory of Ionized Soluten IV The Inrluence of Varlation of Diolostrio Constant on Elmiting Law for Small Concontrations". J. Am, Chom, Soo., 47, 2129-34

Dunning, W. J. and Sohutt, W. J., The D10lootrie Properties or Aquoous Solutions of Salts". Trans. Faraday Soo., 34, 467-79 (1938)

Barl of Berkley, and Hartley, E. A. J., "Further Dotorminatlons of Direet Oamot10 Pressurea", Proc. Roy. Soo. London (A) $92,477-92$ (1916) of Trans ROy Soc. (London), 206, 481-507 (1906)

Barl of Berkley, Hartley, E, O, J., and Burton, C. V., "Omo11. Pressure of Aquoous Solutions of Calcivin Porroojan1de I Conoentrated Solutions", Trans.,Roy. Soc. (London) (1) $209,177-204$

Earl or Berkley, Hartley, E, G, J, and Stephonson, J., "Osmot1. Pressure of Aqueous Solutions of Calolum Perrooyanlde II Woak Solutions", Trans. Roy. Soo. Paraday (A) $209,319-36$ 
Byring, "The Rnergy of Aativation for Blmolecular Reaetion: Involving Hydrogen and the Halogens, Aocording to the Quantim Lechanies", J. Am. Chom, Soe., 53, 2537$49(1931)$

Pajans, K., "Doformation of Ions and Molocules Based Upon Rofractomotr10 Data", 2 Blektrochom., 34, 502-20(1928)

Pajass, K., "Blestrente Struoture of Molooules III Quantization of Molooules". J. Chom. Phys.. 10, 759-60 (1942); "V Stabilization and Bonding of Quantized Radicals", 761; "IV Diffloultios in the Valonee Bond Thoor $\mathrm{J}^{\prime \prime}, 76 \mathrm{~A}^{-1}$

Fajans, K., "Inoomplote Dlssoclation in Solutions of Strong Bloctroljtes". J. Ohem. Phys., 0, 283 (1941)

Pajans, K., "Holar Volumo, Rerraotion and Interionio Porces", J. Chom. Phjo., 9, 282 (1941)

Pajan, K., "Polarizat1on of Ions and Lattioe Distances", J. Ohem. Phys.., 9, 281-2 (1841)

Fajens, X., "Thermal Bxpansion Compressibility and Bleotronic Polar1ziblitty of Ionlo Orystala", Phys. Rov., 61, 543

Fajans, X. and Baner, M., "Blootronle Struoture and Stab111ty of Hydrogen Haildes and of Complex Ions, $\mathrm{XO}_{4}, " \mathrm{~J}$. Chom. Phys. 10, 410-15 (1942)

Pajans, K. and Berlin, T., NBlectronle Struature of Moleoules VI Quantixetion of Molecules Inter and Intra MoloouIar Forees", Phys. Rev, 63, 309-12 (1943)

Fajans, K. and Johnson, O.. "Apparent Volumes of Individual Ions In Aqueous Bolutions," J. An. Chem. Soc. 64, 668-78 (1842)

Fajans, K, and Johnson, O., "Ion-Solvent Intoraction and Ind1T1dual Propertios of Blectroljtes," Mens. Blectrom chom. Soo., 82, 16pp (1942) proprint

Pouard, B., Mosmosetry of Salt Solutions and the Arrenhius theory of Ions", Compt. rend 153, 769-78; J. phya1gno, $5 \mathrm{I}, 627-43$

Puoss, R. M., "Influence of Dipole Plelds Between Solute Molecuía", J. Am. Ohom, Soo., 56, 1027-1050 (1934) 
Chosh, J.C." "A Conmral theory of Lleetrolyte Solutions", $z$. Physik. Ohom, 98, 211-38 (1921)

G111ett, 0." "Aqueous Solutions. Origin of Osmot1e Effects", compt. rond., 177, 257-8 (1923)

G111ett, O.. "Aqueous Solut1ons and Omot1e Pressure," Bull. Soo. Ohtm, belg., 26, 415-8 (1913)

G11lett, C., Mqueous Solut1ona", Verviers. Bull. Soe* belg. Chom., 23, 119-29 (1809)

Glesteon, I. P. and Kraus, C. A., "Properties of Eleotrolyt16 Solutions, XXIII Conduotanee of Several quaternary Onlua Salts in Bthylene Ohloride et $25^{\circ} \mathrm{O} . \mathrm{J} . \mathrm{Am}$. Chen. So0., 69, 45i-54 (1947)

Gopal. R.. "A Statistieal Study of the Variation of Speoifle Condustirity with Coneentration of Bloetrolytes in iquooue Solution:". J. Indian Chom. Soo., 20, 62-8 (1943)

Grine11, Jones, Karol, Kyse1s, and Jude, W., The Measurement of the Conductance of Blectrolytes. IX the Uae of the Cathode Ray 0se1110gxaph as a Deteotor," J. Am. Ohem, Soe., 62, 2929-28 (1940)

Guoker, F. T., The Apparent Holal Fxpansibility of FioetroIytos and the Ooeffielent of Bxpansibility (Thormal Frpansion) as a Punction of Concentration," $J$. An. Ohen. $300.56,1017-21$ (1934)

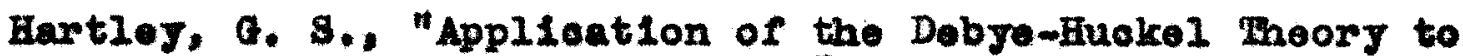
Colloldal Illectrolytes". Trans. Faraday Soo." 31. 31-50 (1935)

Johnson, I. and Laver. V. K., "The Detormination of the Part101. S1ze of Monodieperse Syatems by the Beattering of Light", J, An. Ohem. S00.,69, 1184-92 (1847)

Jones,J. H., Spuhlon, F.J. and Fele1ng, W. A., "The Determination of the Letivity Coeffielents of the Wethrlamine Bjdroehlorides from Freosing Point Data," J. A. Ohen. So0. 64, 965-968 (1942)

Keev11, H. B., "Vaper Pressure of Solutions at High Temperature," J. An. Ohom. So0., 64, 841-850 (1942) 
Wee, P. H. "Holar Polarization and Radius-ratio of Ions", Bature, 155, 698-9 (1945)

London, F., "Properties and Applleatlons of Moleouler Forees", z. phys1k. Chom, Abt, B11, 222-51 (1930)

London, F., "Theory and Systematios of Moleoular Forces," $\mathrm{Z}$. Phys1k., 63, 245-79 (1830)

Malbaum, B. K., "Dieleotrio Constants of Coneentrated Solutiong of Strong Bloctrolytes at 01 tra High Fequenoles", J. Roti. Thooret. Phys. (USSR), I2, 231-45 (1842)

Malor, J. H., "Anomaly of the Mlectrio Conductivity of Oonoentrated Hacl Solution in Region of Deolmoter waves", J. Teoh. PhJs, (USSR), 0, 2004-11 (1839)

Malov, J. H.. Varlation of the Hootrie Conductivity of Bleatrolyto: with Prequenay," J. BxptI. Theoret. Phys, (USSR), 14, 221-3 (1934)

Manchot, W.. Jahratorfor, H., and Zoptor, H., "Gas Solub1lity and Hydrat1on," $z$. anorg. allgem. Chem, 141, 45-81 (2084)

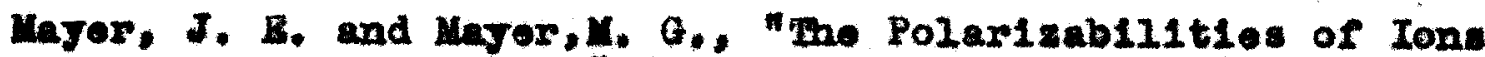
rrom Speetra," Phys. Aov., 43, 605-11 (1933)

Hanty, T. and Valet, K., Mpeolflo Induotive Capaolty of Colloldal Bolutions", Compt. rend., 194, 883-4 (1932)

Hoyos, A. A., "The Interionie Attraction Theory of Ionised Solutes. I Crition Presentation of Theory," J. Am, Ohom. Soe.. 46, 1080-98 (1924)

Hoyes, A. A., "The Intorionlo Attraotion Theory of Ionized SoIutes II Testing of Thoory with Rxperimontel Data," J. Am. Oben. Soo., 46, 1098-2126 (1984)

Moyes, A. A., and Baxter, W. P., "Interlonle Attraotion Theors of Ionlzed Solutes. III Teating of the Theory in Alooholle Bolvonts," J. Am, Chom. Soo., 47, 2122-9 (1925)

Ostwald, Wo, and Mundler, K., "The Omosis and Swolling of D1 sporse Systoms," Hollo1d Z., 24, 7-27 (1919) 
Poaree, J. H. and Pumplin, G. O., "The Appearent and Part1al

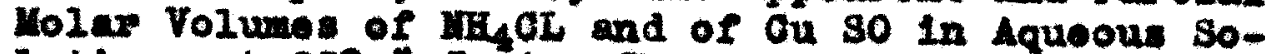
Iut1ons at 280," J. Am. Chom. Soo,. 50, 1221-1288 (1937)

Philippon, H., "A Dew Form of Bleotrlo Resistanos of Fleotro17tes," Bull. Aoad. roy. Bolgigeo, 0losse des wol.. 8, 76-80 and 384-7 (1983)! Chem. Zentr. III, 5 (1923): of Bull. Mosd. roj. Belg18ee, (5) 7, 387

Rey. S., "Eleetrolytes Realatunee with A. O., "Z. Eleetrochen. 36. $545-50(2930)$

Roblason, R.A. and Sandar. D.A., The Aet1vity Coerfielenta of the Alkall Ohlomides and of Lithim Iodide in Aqueous Solutions fron Vapor Presare Measurements," J. Am. Ohem. So . 56, 1830-36 (1934)

Send, H.J.S. Whe Anomaly of Stromg HeotrolJted Bepeolally

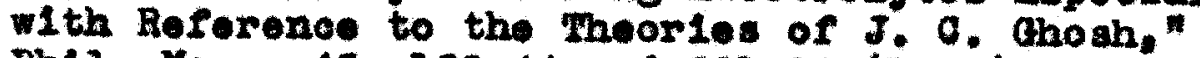
Ph11. Hag. 45, 129-44 and $281-98$ (1923)

Sate, I, V.. Phalnikar, I, L, and Ehide, B. V., "Dieleot1o Constants of Inorganio Salts," J. Indian Chom. Soo. 22. $29-36(1945)$

Seatchard, A.. The Applieation of the Debye-Euckel Theory or Eleotroljtes to Gonoentrated Solutions, "PhJalk. $\mathrm{Z}$., 38. $22-32(1938)$

Seatchard, The Hydration of Suerose in Water Solution as Calculated from Vapor Fressure Measurements," J. Am. Ohom. Soo., 43, 8406-(1921)

Seott, A. F. "Studies in the Solubll1ties of the Soluble 1leotrolytes. V An Eatimation of the Radil of Ions In Saturated Solutions," J. Phs. Qhem., 35, 1410-7 (1935)

Shedioraky, . and Brown, A. S., The Hectrolyte Conduetivity of Alkaline Barth Chiorides in Water at $25^{\circ} \mathrm{C}, " J_{\text {. Au. }}$ Chom. Soo.. 86, 1066-107 (1934)

Shodloviky, T. and HacInnis, D. A. "The Determination of Aotivity Coeffielents from the Potentiala of Coneertra610n 0ella with Transferenee. III KOL. IV CaCl, $J$. An. Ohem. Soe., 59, 508-6 (1937)

Smith, H. W.: "The Nature of Seoondary Valence," J. Phys. Chom, 25, 160-0 (1821) 
Smith, H. W.. "Hature of Secondary Valenee. II Partition Ooefrielonts," J. Phys, Ohan, 25, 204-63 (1921)

Salth, H. W." The Hature of Jecondary Valenoe. III Partition "Coefrielents in the Systom Water-Ether (supplementary notes)" J. Phys. Ohaw., 25, 605-15; 616-27 (1921)

Smith, H. W., "The Nature of Secondary Valenee, IV Partition Coofrielents in the Syatom alyoerol-Aeetone," J. Phys. Chom. 25, 721-34 (1921)

Sintth. H. W.. "The Nature of Secondary Valoine. V Partition Coorrielents in Syatems Containing Veter as One Component with Speelel Referonoe to Absolute Values of Sextes Conatents, J. Phys. Ghom., 26, 256-71; 34957 (1922)

Smith, H. W. and Mite, T. A., The Distribution Ratios of Som Oxganis celds Betreen Water and Organio Iiquids" J. Phys. Uhon., 33, 1953-74 (1829)

Syapes1um, "Ormot10 Pressure", Trans. Faraday Soo., (1917)

Sjuposiu, "The Ionlzation Theory," Trana. Faraday Soe., 15. $1-178(1919)$

SJmposiun, "The Ionization Thoory", Trana. Faraday Soo.. 23, $334(1927)$

T110her, L. M, and Krau:, O. A. Mroperties of Bleotroljt10 Solutiona. XXIV Conduetance of Some Subatituted Armonium Salte in Sthyieno Obioride," J. Am. Ohom. soo., 69, 454-56 (1947)

WJan, J. The Dieleotris Constant of Mixtures of Bthyl Aloohol and Water from 5-40\%," J. Am. Ohom. Soo.. 53. $3892-3301$ (2931)

\section{Vepor Preseure Yeesuring Derioed}

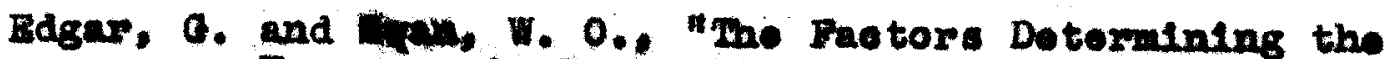
HJgroseople Properties of Soluble Substanees. I The Vapos Pros sures of Saturated solutions, $J$. An. Chom, soo. 44, 570-77 (1922)

GLbeon, R. F. and Ldans, L. H. "Ohanges of Chouloal Potential in Concentrated Solutions of Certain Balts," J. An. Chom. Soe., 55, 2679-95 (1935) 
Lovelace, B. F., Bahlke, W. H, and Frazer, J. O. W., " $A$ study of the Vapor Pressure of Aquoous Solutions of Vann1to," J. Am. Ohom. So0., 42, 1793-1808 (1920)

Lovelace, B. F., Bahlke, W. H. and Fraser, J. C. W., "Vapor Pressures or Lithivm Chloride Solutions at $20^{\circ} \mathrm{C}$, J. An. Chem. Soo.. 45, 2930 (1823)

Mongles, A. W. C., "A Surface Oondensation Error in Certain Meamurements of Vapor Fressure by the Aas Gurrent Saturation Nothod," J. Am. Ohom. Soe.. 48, 978-85 (1920)

Howton, R. F. and IIppotts, B. A., "The Aotivity of Water in Solution of Barlium Chloride," J. Am. Chem. Soo.. 38, 280 (1936)

Pearee, J. H. and Felson, A. F., "The Vepor Preasures of Aquoous Solutions of Lithium Mitrate and the Netivity Coofflelents of some Nikali Salta in Solutions of High Concentration at $25^{\circ} \mathrm{C}, " \mathrm{~J}$. Am. Ohem. S00.. 54, 3544 (1938)

Seatehard, O., Jones, F.T. and Prent1ss, S. S., "The Freesing Polnts of Aqueous Solutions. I A Froesing Polnt Apparatus," J. Am. Chom, Soc., 54, 2676-90 (1032), "II Potassive, Sodium, Lithium Mitrate," 2690-96; "III Ammontum Obloride, Bromide, Iodide, Nitrate. Sulphate," 2696-2708

Stokes, R. H., "The Measuremont of Vapor Pressure of Aquoous Solution: by Bithormal Bquilibration Through the Vapor Phase," J. Am. Chom. So0.. 69, 1291-6 (1947)

Tartar, H. V., Howsohwandor, W. W. and Hess, A. T., "A Thermodynamle Study of the System Zine Sulphate-3ulphurle

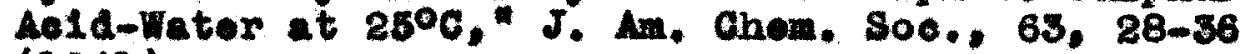
(2841)

\section{Booke}

Dar1a, W. A. and Sadtler, S. S., "Allens Commerelel Organlo Amaljals" 4th odition, Philadelphia, Ponn., P. Blakiston's Sons and Company, 1926

Debje, P., "Polar Molooules" IY, Chomleal Gatalogue Co. 1929

Pajans, K., "Chomleal Foroes and Opt1oal Propertios of Subetances" IX, HoGraw H1II Book Company, 1931 
Falkenhagen, H., "Eleotrolytes"rovised 1934, HY, Oxford Un1versity Preas, 1034

Findley, A, "Osmot10 Pressure" NY, Longmans Green and Co. 1918

Hew1tt, J. T., "Synthot10 Colouring Matters. Dyostuffs Derired From PJridine, Quinoline, Aoridino and Xanthone," MY Longmans, Green and Dompany 1922

H1ldobrand, J.H., "Solub1lity" and odition IIY, ReInhold Pubilshing Corporation, 1936

Jacobs, M. B., "The Ohemistry and Teohnology of Pood and Food Products," Vol. I, pp. 303, TY, Interselence Pub11shers, Ine., 1844

Jones,H.C., "Hature of Solut1ons" MY, D. Van Hostrand Co. 1917

Latimor, W. Y., "Oxidation Potontials" lst edition, HY, Pront1s s-Hall Inoorporated, 1938

Hott, H. P, and Gurnoy, R. W., "Blectronie Processes in Ionlo Gryatals" IIx, Oxford Univarsity Pross, 1940

Pavling. L.. "The Hature of the Ohemioal Bond" and odition, Ithaen, IX, Cornoll Uniroralty Pross, 1945

R10e, 0,K., "Blectronle structure and Ohemlenl Blnding" lst odition, IY, MoGraw Hill Book Company, 1940

Smyth, "Dleleotrie Constant and Moleoular Strueture" IrY, Chemical Catalogue Company, 1931

Tammann, G., "States of Aggregat1on" UY, D, Van Hostrand Co. 1925

Valko, E.t., "Physioal Chemistry of Text1le Proeesses" IT, Interselenes Publishers, 1947

Van Vlock, J.H., NThe Thoory of Elootrio and Magnotio Suseoptibilities" IY, Oxford University Press, 1938 int edition

Von Busachli, A., "Collo1d Syetems" lst odition, (Brpeolally pp, 120-39), IY, Oxford University Press, 1985 
VITA 
Stanley Honry Martin Jury was born of Lowls Bdwin and Gertrudo Bastjan Jury on Marah 3, 1916; at Appleton, W1sconsin. He reoolved hls primary odueation at the First Ward Sehool and the Rooserelt Junlor High Sohool, hls secondary tralning at Appleton Senior Hlgh Sohool, and his colleg? training at the University of Cinolnnat1, recelving his Ohemical Ingineering Degreo in April, 1942. Ho entered the Craduate Sohool in September, 1946, and rooelred his Mastora Dogreo in Ohomleil Bngineoring from the University of Loulavillo in Soptomber, 1947.

At the University of Oineinnat1, Mr. Jury was onrolled in the aooperative plan. As studont engineer he was omployed by the Janesvilie cotton Mills at Janesville, Wisconsin, the Sanitone Division of mery Industries, Ine., at CInoinnat1, Ohlo, and Formioa Insulation Company also at CInolnnat1. He was also a member of the Reservo Officors Training Corp.

After completion of his undergraduate work, Mr. Jury was conmlssioned and ontered upon active duty as Ordnance offleer with the Unitod States Army Ordnance Department. He upent four jears in Britain and hurope returning to the United States in November, 1945. 
Jpon rellef from aotive duty, Mr. Jury assisted a business assooiate in organizing the Polacoat Corporation at Springrield, Ohlo, which was Inoorporated for the purpose of doing researoh and contract engineoring. He resignod in Soptember, 1946, to bocome an inactive member preparatory to his belng placed on graduate status at the UnIrersity of Loulsville.

Ur. Jury is a nember of the National Honor Soclety and Sigme $x_{1}$. 